\title{
MALIGNANT HYPERTHERMIA: AN INVESTIGATION OF FIVE PATIENTS
}

\author{
Beverley A. Britt, M.D., F.R.C.P.(C), ${ }^{1}$ Werner Kalow, M.D., ${ }^{2}$ Alan Gordon, M.D., ${ }^{3}$ \\ JohN G. HuMPHREY, M.D., F.R.C.P.(C) ${ }^{3}$ AND N. BARRY RewCASTLE, M.D., F.R.C.P.(C) ${ }^{4}$
}

\section{INTRODUCTION}

Malignant hyperthermia (MH) with its frequent fatal outcome has found much attention in the literature during recent years. ${ }^{1-6}$ The majority of reports in the literature are case histories. ${ }^{7-99}$ In addition, there are statistical ${ }^{100-102}$ and genetic analyses. ${ }^{44,46,61,81,103-109}$ There are a number of descriptions of malignant hyperthermia in pigs ${ }^{110-119}$ in which the manifestations are similar to those in man. Several biochemical and microscopic ${ }^{120-134}$ studies exploring the cause of porcine malignant hyperthermia have been published, but their results and conclusions are not uniform. Furthermore, at the present state, it is not clear to what extent these animal data are applicable to man. Probing studies conducted on human survivors of malignant hyperthermia are still relatively few and inconclusive, ${ }^{99,135-151}$ while speculations on its aetiology and pathophysiology are frequent and contradictory. ${ }^{152-183}$

The present paper gives an account of human investigations conducted over the past several years in Toronto. These studies were performed on subjects, each of whom was from an independent family. With one exception, each had at some time in the past survived a severe episode of malignant hyperthermia, ${ }^{103,184-187}$ but was deemed to be fully recovered at the time of investigation. The exception had several close relatives who had died of $\mathrm{MH}$. The subjects were hospitalized in Toronto for the specific purpose of submitting to the investigations to be described, for which they gave their informed consent.

There are many observations which indicate that the genetic defect which gives rise to malignant hyperthermia on exposure to anaesthetics, must reside in skeletal muscle. ${ }^{10,17,26,74,81,99,101,108,109,141,143,145,146,150,158,187,188,189}$ This is not to say that the defects must be confined to skeletal muscle, nor does this necessarily mean that a defect in muscle is the primary lesion. ${ }^{99,140,147,148,151}$ Nevertheless, since it can be regarded as certain that skeletal muscle is involved in malignant hyperthermia, most of the investigations were aimed at testing this tissue, and skeletal muscle biopsies were therefore obtained. Control specimens were obtained from muscle that had to be removed during surgery, primarily during orthopaedic and thoracic operations. For the blood tests conducted, established normal values for each method were used as a basis for comparison.

From the Departments of Anaesthesia 1 , Pharmacology, ${ }^{2}$ Medicine (Division of Neurology) ${ }^{3}$ and Pathology (Neuropathology) ${ }^{4}$, University of Toronto and Toronto General Hospital. 


\section{Cuinical History of Patients Investigated}

Patient $A^{187}$ was a 24 -year-old man who at the age of 23 years was anaesthetized for repair of a congenital inguinal hernia. After a sequence of thiopentone, halothane and succinylcholine, he developed rigidity and fever which were detected early and treated with cooling, hyperventilation with 100 per cent oxygen, cortisole (Solucortef) and sodium bicarbonate. The main complication was acute renal shutdown, secondary to myoglobinuria, which required treatment by artificial kidney dialysis for one month. Another post-operative problem was massive swelling and excruciating pain and tenderness of the leg muscles.

Fifteen months later, at the time of investigation, he complained of moderate weakness of the quadriceps muscles and transient muscle cramps on vigorous exercise, both of which phenomena had existed prior to the anaesthetic. His muscle bulk was great but power of the quadriceps was moderately weak and there was a ptosis of the left eye. Power of the remaining muscles was good. Two siblings and his father had ptosis of the left eye and two paternal uncles had died of malignant hyperthermia.

Patient $B^{184}$ was a 22-year-old female who, when 21 years of age, required anaesthesia for removal of an ovarian cyst. The anaesthetic agents used were thiopentone, succinylcholine and halothane. After 90 uneventful minutes, there was a sudden onset of rigidity and tachycardia and the temperature rapidly rose to $112^{\circ} \mathrm{F}$. Besides cooling, sodium bicarbonate, cortisol, insulin and glucose, she received an infusion of $800 \mathrm{mg}$ of procain amide, whereupon the temperature fell to $95^{\circ} \mathrm{F}$ within 19 minutes. She had red urine, some impairment of renal function, marked weakness of the leg muscles and severe generalized muscle pain during her convalescence.

On assessment 19 months after the anaesthetic she complained of frequent spontaneous muscle cramps. These could be elicited at will in the left rectus femoris by maximal exercise against resistance. Her muscles were well developed with no evidence of weakness. It was discovered at this time that two paternal relatives had also had episodes of malignant hyperpyrexia.

Patient $C^{186}$ was a 14-year-old boy who, during anaesthesia for repair of a squint at the age of 10 years, developed a fever of $108^{\circ} \mathrm{F}$, extreme rigidity, acidosis, cyanosis, hyperkalaemia, myoglobinuria and arrhythmias. The anaesthetic agents were thiopentone, succinylcholine, halothane and nitrous oxide. Treatment consisted of cooling, sodium bicarbonate and diuretics.

On examination four years later, he was found to be strikingly muscular and powerful but with an unrepaired strabismus. No other neurological or muscular abnormalities were detected. Subsequent to the proband's anaesthetic the father developed a fatal episode of malignant hyperthermia during a methoxyflurane curare anaesthesia.

Patient $D^{103}$ was a 45 -year-old alcoholic man who developed a duodenal ulcer. Following a haematemesis at the age of 44 he was anaesthetized with thiopentone, succinylcholine, cyclopropane and nitrous oxide. His temperature rose shortly to $108^{\circ}$ F. Hyperpnoea, tachycardia, hyperkalaemia, acidosis, myoglobinuria and oliguria occurred. Failure of blood clotting and coma with fixed and 
dilated pupils persisted for some time postoperatively. He was revived by hyperventilation with oxygen, abdominal cooling, mannitol, sodium bicarbonate, antipyretics and haemodialysis. Convalescence was characterized by muscle weakness which gradually disappeared.

At no time during this crisis was rigidity observed. Its prominent presence, however, in an affected niece intimates that he belongs to the same aetiological category as volunteers A, B, C and E. Absence of rigidity in this individual may have been due to the use of a weak triggering agent (cyclopropane) or to an innately mild defect.

At the time of assessment ten months later, he denied any history of muscle cramps or weakness. On examination the muscles were well developed without evidence of weakness or wasting.

Patient $E^{185}$ was a 42 -year-old female who had not herself had an episode of malignant hyperpyrexia. Her father, brother and son, however, had all died of MH episodes characterized by muscle rigidity, tachycardia, cyanosis and acidosis.

On investigation, she did not complain of muscle weakness or cramps. Her muscles were excessively large and powerful and no areas of atrophy were demonstrable.

\section{Methods}

\section{Blood Biochemical Studies}

Creatine Phosphokinase was measured by a modification of the kinetic method of Rosalki. ${ }^{190}$ Enzyme activity was determined by measuring the rate of reduction of nicotinamide adenine dinucleotide phosphate (NADP) at $340 \mathrm{~nm}\left(25^{\circ} \mathrm{C}\right)$ using a Gilford 2000 recording spectrophotometer.

$$
\begin{aligned}
& \text { Reaction: } \\
& \text { creatine phosphate }+ \text { ADP } \stackrel{\text { CPK }}{\longrightarrow} \text { creatine + ATP } \\
& \text { ATP + Glucose } \stackrel{\text { Hexokinase }}{\longrightarrow} \text { G-6-P + ADP } \\
& \text { G-6-P + NADP } \stackrel{\text { G-6-PDH }}{\longrightarrow} \mathrm{NADPH}_{2}+6 \text {-phosphogluconate }
\end{aligned}
$$

Calbiochem CPK Fast-Pack reagents were used to provide the buffered substrates and NADP. Dithiothreitol was added to activate the enzyme.

Lactate Dehydrogenase was measured by a modification of the kinetic method described by Wroblewski and La Due. ${ }^{191}$ Enzyme activity was determined by measuring the rate of oxidation of $\mathrm{NADH}_{2}$ with pyruvate as substrate, at $340 \mathrm{~nm}$ $\left(25^{\circ} \mathrm{C}\right)$ using a Gilford 2000 recording spectrophotometer.

Reaction:

$$
\text { pyruvate }+\mathrm{NADH}_{2} \longleftrightarrow \text { lactate }+\mathrm{NAD}
$$

Lactate was measured by Jones' modification of the method of Savory and Kaplan. ${ }^{192}$ The method was based on the oxidation of lactate to acetaldehyde by ceric sulphate. Acetaldehyde was then measured by gas chromatography. 
Pyruvate was determined by a modification of the method of Bucher et al. ${ }^{193}$ The method is based on the reduction of pyruvate to lactate in the presence of $\mathrm{NADH}_{2}$ and LDH. Pyruvate was calculated from a measurement of the oxidation of $\mathrm{NADH}_{2}$ at $340 \mathrm{~nm}$, using a Gilford 2000 recording spectrophotometer.

Reaction:

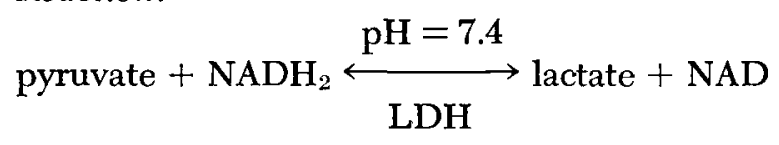

Calcium and Magnesium were measured by the automated method of Porter and Kallweit. ${ }^{194}$ A technicon Sampler II and proportioning pump provided an automated dilution of 1:35 in 1 per cent lanthanum oxide. $\mathrm{Ca}$ and $\mathrm{Mg}$ were measured under steady state conditions using a modified Perkin Elmer 303 atomic absorption spectrophotometer.

Inorganic Phosphate was determined by the Autoanalyser N-4a Method, ${ }^{195}$ a modification of the Fiske and Subbarow procedure. ${ }^{196}$ This method is based on the formation of phosphomolybdic acid which is then reduced by 1-amino-2naphthol-4-sulphonic acid. The blue complex is measured colorimetrically at $660 \mathrm{~nm}$.

Other Blood Biochemical Studies. Urinary catecholamines, serum thyronine, protein bound iodine, radioactive iodine uptake, serum triglycerides, cholesterol and phospholipids, serum creatine and serum creatinine were determined by standard techniques.

\section{Skeletal Muscle Studies}

\section{Electromyography (EMG)}

EMG $^{197}$ was carried out using standard techniques. Concentric needle electrodes were placed in the right deltoid and right quadriceps femoris muscles. The EMG pattern was recorded and observed during maximal and minimal voluntary contraction. In each muscle a search for spontaneous muscle activity was carried out.

\section{Muscle Biopsies - Clinical Aspects}

Muscle biopsies were obtained for morphological, biochemical and pharmacological studies. Fifteen to twenty grams was excised from the vastus lateralis of each patient. For each study, control muscle was also removed from several patients free of the MH trait, who were undergoing various surgical operations. Relief of pain for the affected patients was provided by epidural anaesthesia using 2 per cent procaine without epinephrine, or 2 per cent mepivacaine.

\section{Microscopy}

Paraffin Sections - Two muscle fascicles were obtained from each patient. After air drying for ten minutes, one was incubated in Bouin's solution and the other in Zenker's solution. The fascicles were then placed in paraffin and cut to 6 microns 
thickness. Sections prepared by each method were stained with Haematoxylin and Eosin (H\&E) and by the Gomori technique.

Histochemical Studies ${ }^{198}$ were performed on patients B, D and E. One end of a muscle fascicle was carefully freed from the surrounding muscle. This free end was secured by a fine silk suture. The remainder of the fascicle, one half $\mathrm{mm}$ in diameter by one and a half $\mathrm{cm}$ long, was then dissected free and frozen in isopentane which had been cooled in liquid nitrogen. Sections were cut to 6 microns and stained for periodic acid Schiff (PAS) without diastase digestion (to stain for carbohydrate except glycogen), trichrome (to reveal structural alteration), myo-phosphorylase, succinic dehydrogenase, nicotine adenine dinucleotide dehydrogenase (NADase) and myofibrillar adenosine triphosphatase (ATPase) at both $\mathrm{pH} 9.6$ and $\mathrm{pH} 4.5$. Histograms were carried out on the ATPase slides to determine the distribution and size of type I fibres (rich in mitochondrial and oxidative enzymes) and type II fibres (rich in triads and glycolytic enzymes) ${ }^{199}$

Glutaraldehyde Sections ${ }^{200}$ - Two final muscle fascicles from patients B, D and $\mathrm{E}$ (each $1 \mathrm{~mm}$ in diameter and $1 \mathrm{~cm}$ long), were tied with a suture at each end. After freeing the main body of the fascicle, the specimen was then stretched slightly to maintain fibre orientation. One piece was treated with 2 per cent osmium, glutaraldehyde and 5 per cent phosphate buffer at $\mathrm{pH} 7.4$ and the other with glutaraldehyde and phosphate buffer only. The central portions of the specimens were then dissected into cross and longitudinal sections, dehydrated in graded alcohols and embedded in Epon. Thin sections (1/2 microns) for light microscopy were stained with paraphenylene diamine. Ultra thin sections (600$800 \AA$ ) were mounted on 200-300 mesh uncoated grids stained with uranyl acetate and PBK lead, and then examined in a Phillips 200 microscope.

\section{Mitochondria}

The mitochondria were prepared by modifications of standard methods. ${ }^{201,202}$ Five grams of muscle were minced, rinsed and suspended in two volumes of a modified Chappel-Perry medium (a proteolytic enzyme) ${ }^{203}$ (Table I). After the addition of $20 \mathrm{mg}$ Nagarse, the mince was rapidly homogenized by hand with a TRI-R glass and Teflon pestle and further diluted with an equal volume of the medium. The preparation was left on ice for 10 minutes and was then rehomogenized and further diluted with the same medium to $200 \mathrm{ml}$. The suspension was centrifuged twice for 10 minutes at $600 \mathrm{~g}$. The supernatant was then centrifuged at $8500 \mathrm{~g}$ for another 10 minutes. The pellets were rinsed, suspended in a sucrose containing high speed preparation medium (Table II). After a final centrifugation at $14,000 \times \mathrm{g}$ for 10 minutes the pellets were rinsed and suspended in the high speed preparation medium and ready for use. Mitochondrial protein was measured by the Biuret method. ${ }^{204}$

All the remaining steps were carried out at $25^{\circ} \mathrm{C}$. Approximately $500 \mu \mathrm{g}$ of mitochondrial protein was added to $1.5 \mathrm{ml}$ of a reaction medium ${ }^{205}$ (Table III). One litre/minute of air was passed through a calibrated Mark III Fluotec halothane vaporizer. The vapour then went for three minutes through the tightly stoppered and constantly agitated reaction chamber.

The concentrations of halothane in air were $0,0.5,1.8$ and 5.0 volumes per cent. 
TABLE I

Low Speed Preparation Medium for Mitochondria

(Modified Chapell-Perry Medium)

\begin{tabular}{ll}
\hline \hline 0.10 & M KCl \\
0.05 & M Tris-HCl buffer, $\mathrm{pH}=7.4$ \\
0.001 & $\mathrm{M} \mathrm{Na-ATP}$ \\
0.005 & M MgSO \\
0.001 & M EGTA \\
$0.50 \%$ & Crystalline bovine serum albumin \\
pH of medium adjusted to 7.4 at $4^{\circ} \mathrm{C}$ \\
\hline
\end{tabular}

TABLE II

High Speed Preparation Medium for MITOCHONDRIA

\begin{tabular}{ll}
\hline 0.10 & M Sucrose \\
0.005 & $\mathrm{M}$ Tris- $\mathrm{HCl}$ buffer, $\mathrm{pH}=7.4$ \\
0.015 & $\mathrm{M} \mathrm{KCl}$ \\
0.0005 & $\mathrm{M} \mathrm{MgCl}$ \\
0.00025 & $\mathrm{M}$ EDTA \\
$1.0 \%$ & Crystalline bovine serum albumin \\
pH of medium adjusted to 7.4 at $4^{\circ} \mathrm{C}$ \\
\hline
\end{tabular}

TABLE III

Reaction Medium for Mitochondria

\begin{tabular}{ll}
\hline \hline 0.015 & M KCl \\
0.03 & M phosphate buffer, $\mathrm{pH}=7.4$ \\
0.025 & M Tris-HCl buffer, $\mathrm{pH}=7.4$ \\
0.0005 & M MgCl \\
0.045 & M Sucrose \\
0.02 & M Glucose \\
0.00025 & M EDTA \\
0.01 & M Mannitol \\
$0.2 \%$ & Crystalline bovine serum albumin \\
pH of medium adjusted to 7.4 at $25^{\circ} \mathrm{C}$ \\
\hline
\end{tabular}

These concentrations and the time of equilibration were selected to give an intramitochondrial concentration range spanning that which is thought to exist in vivo during normal anaesthesia. ${ }^{206-208}$ Separate mitochondrial aliquots were used for each dose of halothane.

The $\mathrm{QO}_{2}$, i.e. the microatoms of oxygen consumed per milligram of mitochondrial protein per minute, was measured by a tightly fitting, modified Clark oxygen electrode (Yellow Springs). The system was thus anaerobic, apart from the oxygen which remained dissolved in solution. The substrates used were 10 $\mathrm{mM}$ succinate and a mixture containing $10 \mathrm{mM}$ glutamate and $10 \mathrm{mM}$ malate. Respiration was measured both in the presence of $0.1 \mathrm{mM}$ ADP (state 3 respiration or $Q_{3}$ ) and after the ADP had become exhausted (state 4 respiration or $Q_{4}$ ). The respiratory control index ( $\mathrm{RCI}$ ) was calculated as the ratio of state 3 to state 4 respiration. The ratio of micromoles of ADP added to microatoms of oxygen consumed, i.e. the $\mathrm{P} / \mathrm{O}$ ratio, was also determined. For each muscle preparation the order of exposure to the different doses of halothane was varied. For each mitochondrial sample the measurement was repeated twice or more. 
TABLE IV

Human Krebs Ringer's Solution

\begin{tabular}{rl}
\hline 118.4 & $\mathrm{mM} \mathrm{NaCl}$ \\
3.3 & $\mathrm{mM} \mathrm{KCl}$ \\
.9 & $\mathrm{mM} \mathrm{MgSO}_{4}$ \\
1.1 & $\mathrm{mM} \mathrm{KH}_{2} \mathrm{PO}_{4}$ \\
11.1 & $\mathrm{mM} \mathrm{Glucose}$ \\
24.9 & $\mathrm{mM} \mathrm{NaHCO}_{3}$ \\
2.5 & $\mathrm{mM} \mathrm{CaCl}$ \\
$\mathrm{pH}$ of medium adjusted to 7.4 at $25^{\circ} \mathrm{C}$
\end{tabular}

TABLE V

Sucrose-Imidazole Preparation

MEDIUM FOR SARCOPLASMIC RETICULUM

$0.3 \quad$ M Sucrose

0.01 M Imidazole

$\mathrm{pH}$ of medium adjusted to 7.0 at $25^{\circ} \mathrm{C}$

\section{Study of Isometric Contraction of Isolated Muscle}

For the pharmacological studies, some control specimens were obtained simultaneously with the samples removed for the biochemical studies but, independently, additional specimens were obtained from pectoralis muscle removed during mastectomy for cancer.

A muscle strip $2 \mathrm{~cm}$ long and $3 \mathrm{~mm}$ thick was mounted for measurement of isometric contraction, as described by Kalow and co-workers, ${ }^{145}$ within 10 to 15 minutes of removal from the patient. The muscle on its mount was immersed in a bath of $30 \mathrm{ml}$ containing glucose, sodium, potassium, calcium, magnesium, chloride, bicarbonate, and phosphate in concentrations resembling those of human plasma (Table IV). Carbogen was bubbled through the bath. The $\mathrm{pH}$ was 7.3 and the temperature was $25^{\circ} \mathrm{C}$. The resting tension was adjusted to 0.5 grams. Isometric tension was continuously recorded by a transducer and a Grass polygraph. The muscle was stimulated every five seconds through platinum electrodes from a square-wave generator to produce a brief twitch. Various concentrations of caffeine $(0.3-32 \mathrm{mM})$ were added directly to the bath. Halothane was added to the carbogen in desired concentrations $(0,1.0,2.0$ and 5.0 volumes per cent) with the help of a calibrated Dragerwick halothane vaporizor. Once started, the halothane flow was continued while different concentrations of caffeine were added to the bath and washed out again. Only the caffeine effects were completely reversible within minutes.

\section{Sarcoplasmic Reticulum}

Sarcoplasmic reticulum was isolated by a modification of standard techniques. ${ }^{209}$ Five grams of muscle was minced and washed at $4^{\circ} \mathrm{C}$ in a sucrose-imidazole preparation medium (Table V). The mince was suspended in $80 \mathrm{ml}$ of the preparation medium and homogenized with four passes of a Potter Elvejihm motor driven pestle. The homogenate was centrifuged twice at $1,500 \mathrm{~g}$ for 20 minutes. The 
TABLE VI

Reaction Medium for Sarcoplasmic RETICULUM

$\begin{array}{ll}0.1 & \mathrm{M} \mathrm{KCl} \\ 0.2 & \mathrm{M} \mathrm{Imidazole} \\ 0.005 & \mathrm{M} \mathrm{MgCl} \\ 0.004 & \mathrm{M} \mathrm{K} \text { oxalate } \\ 0.0002 & \mathrm{M} \mathrm{Ca} \mathrm{Cl}_{2} \\ \text { pH of medium adjusted to } 7.0 \text { at } 25^{\circ} \mathrm{C} \\ \text { ATP Solution } \\ 0.005 \mathrm{M} \text { ATP with } \mathrm{pH} \text { adjusted to } 7.0 \text { at } 25^{\circ} \mathrm{C}\end{array}$

supernatant was then centrifuged first at $10,000 \mathrm{~g}$ for 30 minutes and finally at $48,200 \mathrm{~g}$ for 90 minutes. The pellet was resuspended and diluted with the preparation medium. Quality was assessed by electron microscopy. Sarcoplasmic reticulum protein was determined by the Biuret method. ${ }^{204}$

An incubation medium containing both cold and radioactive calcium chloride (Table VI) was equilibrated for three minutes with air or with $0.5,2.0$ or 5.0 per cent halothane vapour delivered from a calibrated Mark III "Fluotec." The sarcoplasmic reticulum was then added to the medium and the calcium uptake reaction was initiated by the addition of sufficient ATP (Table VI) to give a concentration of $0.005 \mathrm{M}$. The reaction was terminated after five minutes by passing the tightly sealed mixture through a $0.45 \mu$ millipore filter. Radioactivity in the filtrate was counted in a Tricarb liquid scintillation counter. Total loading of the sarcoplasmic reticulum with calcium during the five-minute reaction period was calculated by subtracting the count obtained for a control filtrate from that obtained for the sarcoplasmic reticulum filtrate.

\section{RESULTS}

\section{Blood Biochemical Studies (Table VII)}

The creatine phosphokinase (CPK) was elevated in all patients. The elevation in patient $\mathrm{B}$ was modest, in spite of a temperature of $112^{\circ} \mathrm{F}$ and marked myoglobinuria during her halothane and succinylcholine anaesthetic. As might be expected CPK values rose in all volunteers following the trauma of their muscle biopsy and then fell following a week of inactivity to a level less than the preoperative value.

Other serum enzymes, namely the lactic dehydrogenase (LDH), hydroxybutyric dehydrogenase (HBDH), and glutamic oxalic transaminase (GOT) were either normal or showed only modest and inconsistent elevations.

Serum calcium values were normal in all patients, as were serum phosphate values. Serum magnesium values were all low normal.

Serum pyruvate values tended for the most part to be slightly elevated. Serum lactate determinations, on the other hand, were normal except for a slight elevation in patient $B$.

Thyroid function, urinary catecholamines, serum creatine, serum creatinine, and serum lipids were within normal limits in all patients. 
BRITT, et al.: MALIGNANT HYPERTHERMIA

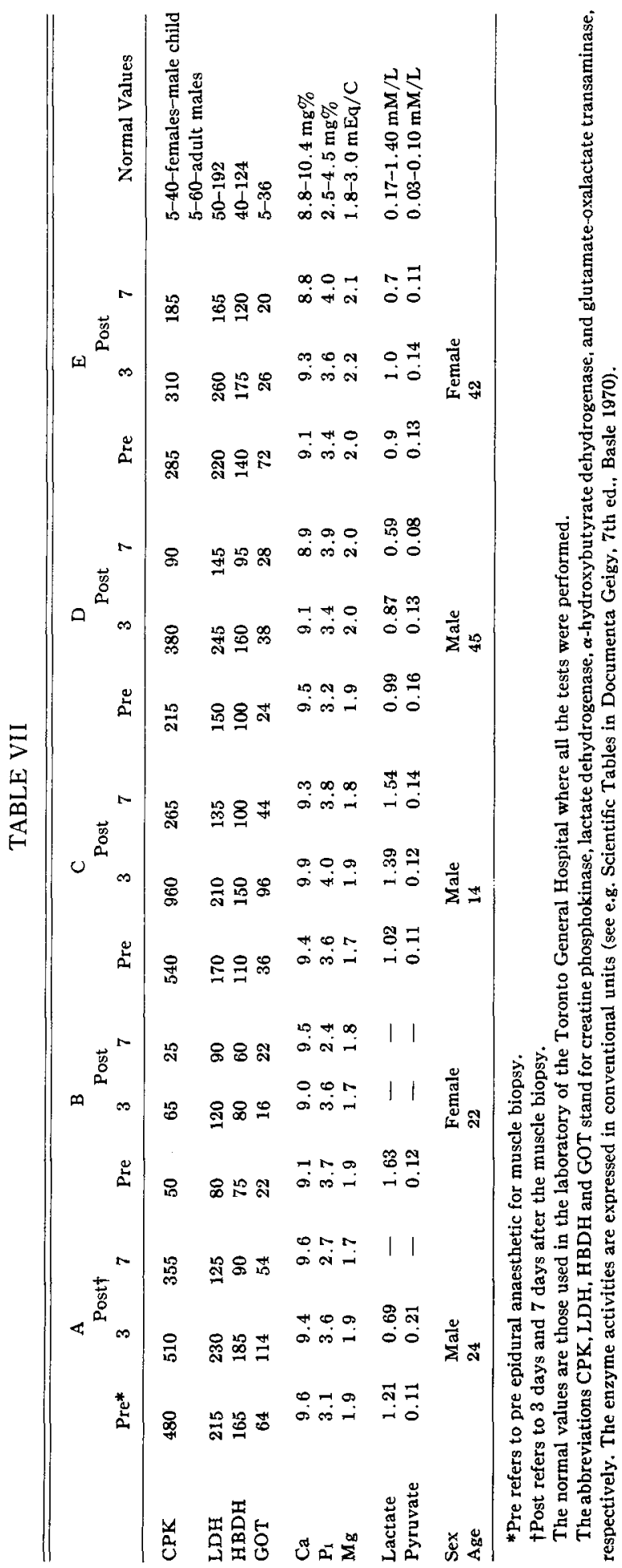




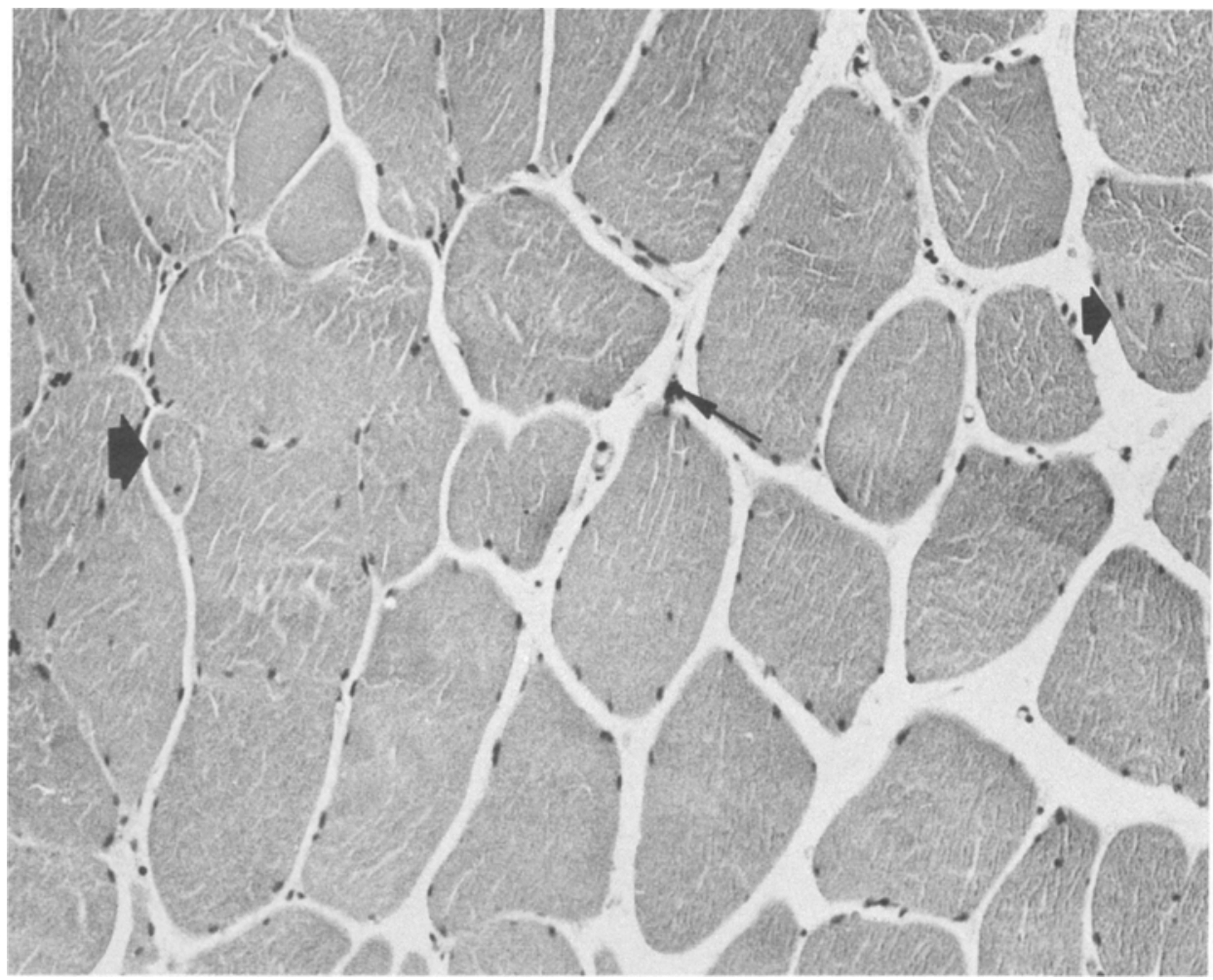

Figure 1. Great variability in fibre size is seen with normal, small and large fibres. There are occasional tiny fibres with clumps of dark pyknotic nuclei (thin arrows). Some fibres, both large and small contain internal nuclei (thick arrows). Patient A. Haematoxylin and Eosin. Mag. $\times 184$.

\section{Electromyography}

Patient A-Electromyographic pattern of the right deltoid and the right quadriceps femoris showed occasional bizarre polyphasic potentials. Maximal effort produced a full interference pattern and there was no spontaneous activity.

Patient $B$-Electromyography of the right deltoid and the right quadriceps femoris muscles was unremarkable.

Patient $C$-Areas were found in the right deltoid in which the motor unit potentials were reduced in amplitude and duration and the number of short polyphasic potentials was increased (to $20-30$ per cent of all potentials). There was no spontaneous activity or fibrillation potentials and the interference pattern was full.

Patient $D$ - The right quadriceps was normal but the right deltoid showed a moderate increase in the incidence of short polyphasic potentials. At no time was there spontaneous activity. The interference pattern was normal.

Patient E - The right deltoid displayed non-specific alterations with a frequency of polyphasic potentials greater than normal. Ágain, no spontaneous motor units or fibrillation potentials could be detected and the interference pattern was full. 


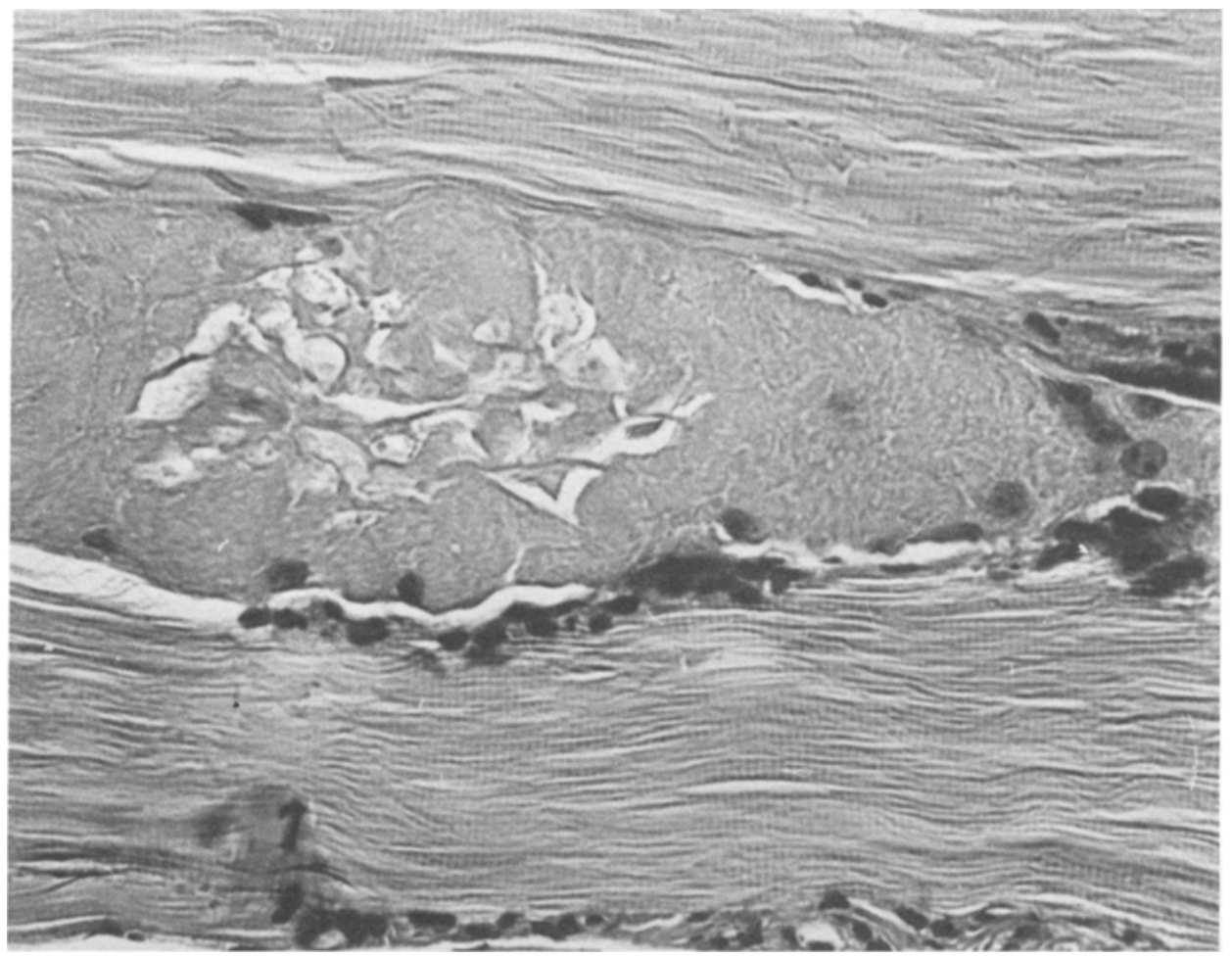

Figuae 2. A focally necrotic fibre shows obvious loss of cross striations when compared to structurally normal adjacent fibres. (Patient A.) Haematoxylin and Eosin. Magnification $\times 460$.

\section{Microscopy}

Patient A-Paraffinized tissue only was available for examination. There was variation in fibre size with both large and small fibres and scattered small atrophic fibres containing collections of dark pyknotic nuclei (Figure 1). One fibre showed focal necrosis (Figure 2) and close by, on serial sections, a collection of macrophages was evident.

Patient $B$ - The muscle fibres tended to be small, many being in the $30-50 \mu$ range (normal 30-70 $\mu$ ). On histographic analysis the mean diameter of both type I fibres and type II fibres was $55 \mu$. There were no structural changes and the intramuscular nerve was normal. Histochemical reactions were normal. The material received for electron microscopy was poorly preserved, marring interpretation; however, no abnormality was seen in the material examined.

Patient $C$-Interpretation was marred by poor preservation. Paraffin sections revealed the muscle cell architecture to be generally normal but there were occasional small angular fibres. There was a single focal collection of macrophages.

Patient $D$-Cross-sections exhibited great variation of fibre diameter. There were frequent large fibres, some of which contained internally situated nuclei. Scattered tiny fibres, usually represented by clumps of dark pyknotic nuclei were also present (Figure 3). A rare fibre was necrotic and there was a single perivascular round cell collection. An occasional small dark staining fibre was seen 


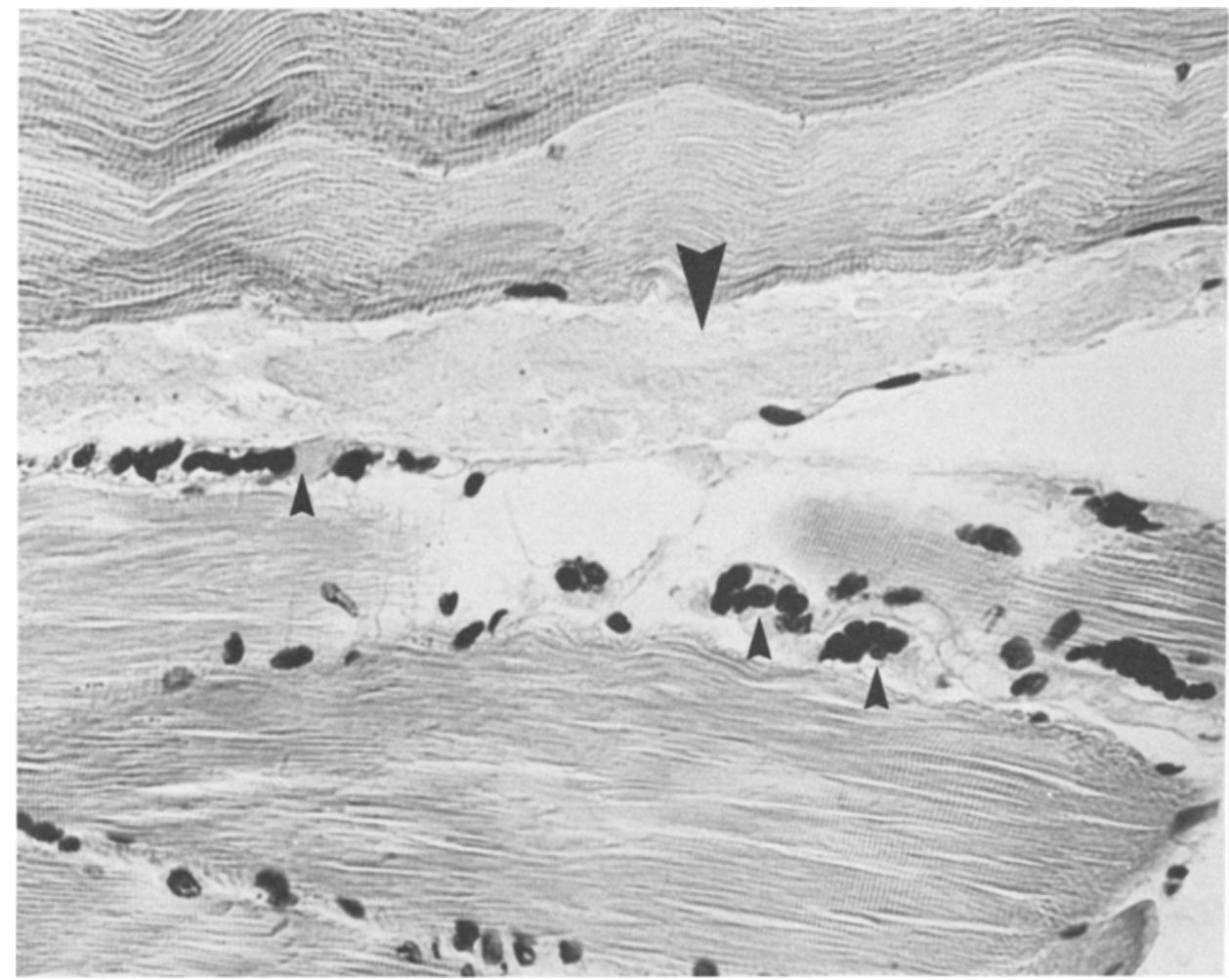

Figure 3. Normal muscle fibres are shown with cross-striations and subsarcolemmal nuclei. Several tiny atrophic fibres are present with homogeneous of granular sarcoplasm and clumps of dark pyknotic nuclei (small arrows). In addition, one large diameter fibre has become necrotic (large arrows). Patient D.

Haemotoxylin Eosin stain. Magnification $\times 460$.

on the oxidative enzyme preparations. A histogram carried out on the myofibrillar ATPase sections showed that type I fibres ranged in diameter from 50 to $100 \mu$ while type II fibres varied from 35 to $110 \mu$ in diameter (Figure 4). The peak was therefore skewed to the right in favour of large fibres. Atrophy-hypertrophy factor analysis revealed a significant non-type-selecting muscle fibre hypertrophy. The tiny fibres apparent in the paraffinized sections were not seen in the ATP-ase slides, accounting for their absence in the histogram. The intramuscular nerves were normal. Electron microscopy studies failed to show any abnormalities in myofibril organization, transverse tubules, sarcoplasmic reticulum or the mitochondrial structure, though some prominent mitochondrial aggregates and lipochrome were observed.

Patient E - Again great variation of fibre size was apparent. There were striking collections of large fibres, some of which contained internally situated nuclei. Many small round or angular fibres were also present, containing aggregates of dark pyknotic nuclei. Some of the intramuscular nerves exhibited excessive endoneural and perineural connective tissue and loss of myelinated nerve fibres. Targetoid fibres were seen in the Gomori trichrome and NAD and SDH stained 


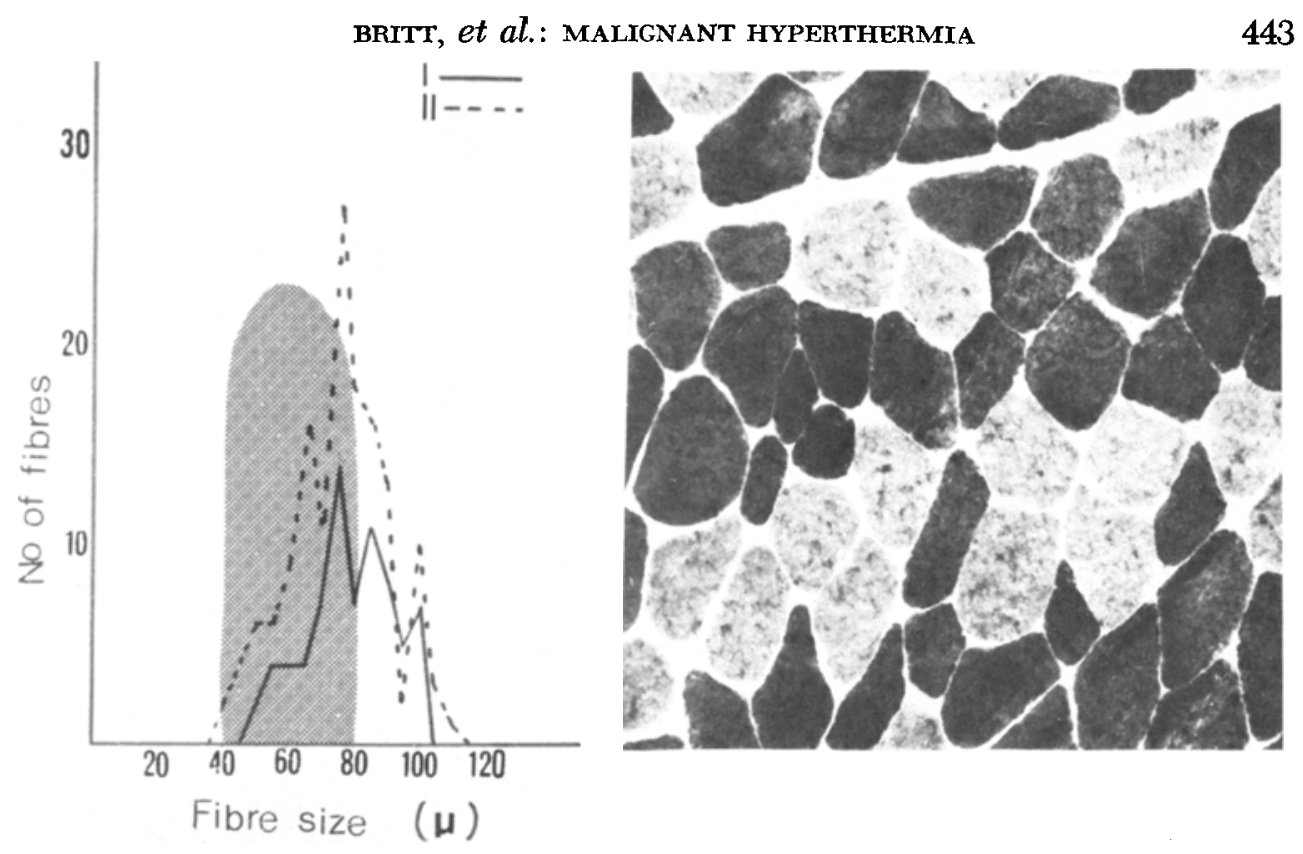

FIgure 4. To the right, is a frozen section stained for myofibrillar ATP-ase at $\mathrm{pH} 9.6$. There is a normal distribution of light type I and dark type II fibres with some variation in fibre size. To the left is a histographic analysis of fibre diameters with the grey area representing the normal range $(40-80 \mu)$. Both type I fibres (solid line) and type II fibres (dotted line) demonstrate a shift to the right, indicating an increase of large diameter fibres. (Patient D.)

Myofibrillar ATP-base. Mag. $\times 180$.

histochemical sections (Figure 5). A histogram of the ATPase preparation showed type I fibres vary from $70 \mu$ to $150 \mu$ with a mean of $105 \mu$ and type II fibres ranging from $45 \mu$ to $135 \mu$ with an average of $100 \mu$. The ATPase preparation did not contain the small fibres of $15-30 \mu$ which were scattered in small numbers throughout the paraffinized preparations. The epon embedded sections displayed some fibres with excessive amounts of lipid. Ultrastructural studies demonstrated both atrophic and more structurally normal fibres. Specific abnormalities demonstrated in the atrophic fibres were extensive disorganization of myofibrillar material, autophagic vacuoles with lamellated material and tubular aggregates (Figure 6). Fibres of more normal size showed foci of sarcomere streaming (Figure 7), mitochondrial aggregates, prominent collections of glycogen and lipochrome pigment. No demonstrable abnormality could be found in the " $T$ " system, endoplasmic reticulum or in the structure of the mitochondria (Figure 8).

\section{Mitochondria}

As Table VIII indicated, in the presence of the NAD-linked substrates glutamate and malate and in the absence of halothane, the $Q_{3}, Q_{4}$, R.C.I. and $P / O$ ratios of the skeletal muscle mitochondria from the malignant hyperthermic patients were not significantly different from those of the control patients. More- 


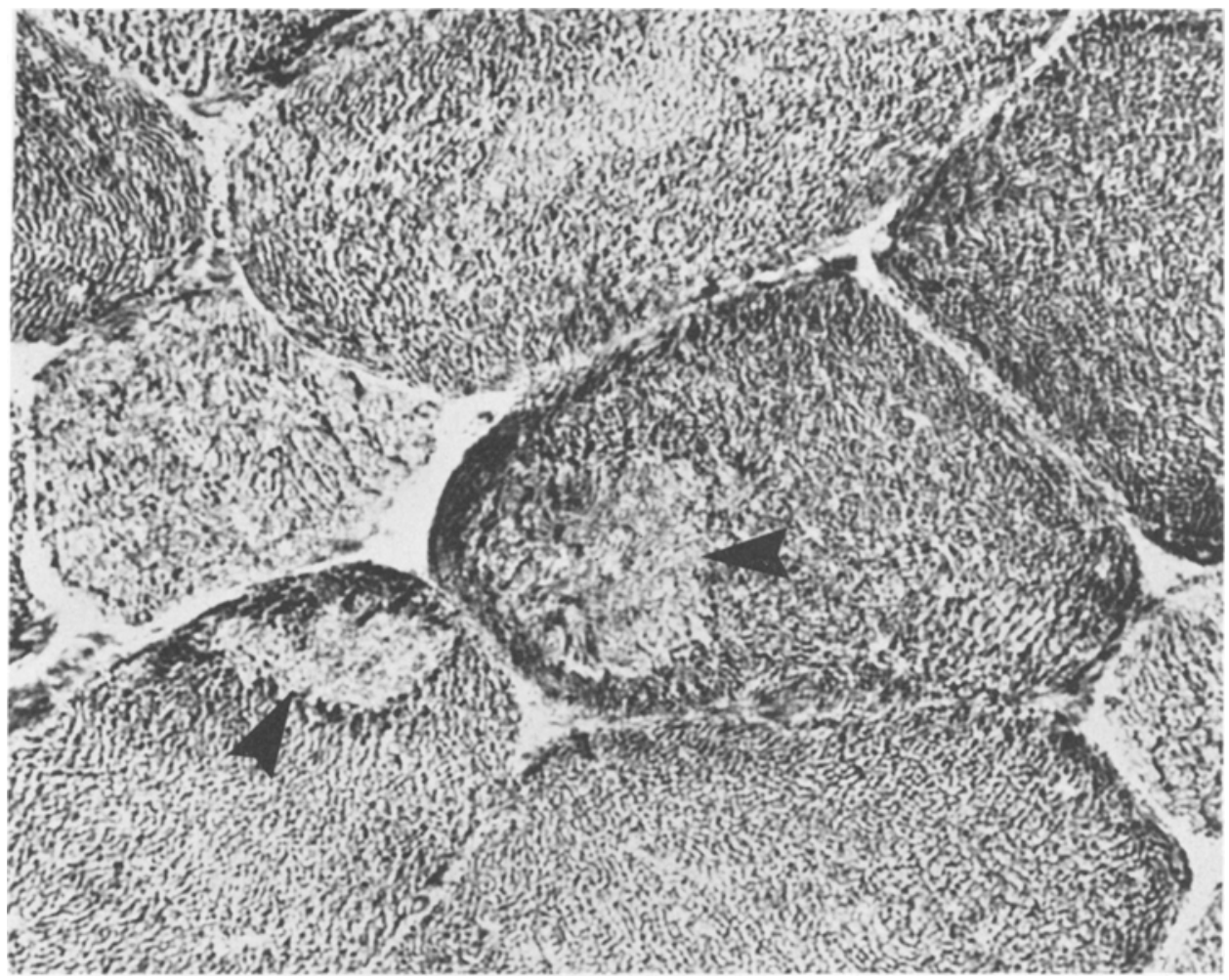

Figure 5. Definite targetoid changes with focal decrease of rnitochondria are present in two of the type I fibres (arrows). Patient E.

Nicotinamide Adenine Dinucleotide (Mitochondrial Reaction). Magnification $\times 730$.

over, there were no substantial differences in these parameters among the five hyperthermic patients.

Halothane (Tables VIII-IX) markedly inhibited state 3 glutamate and malate respiration in both the normal and the $\mathrm{MH}$ affected patients. The $\mathrm{Q}_{4}$ of the normal and the hyperthermic mitochondria was unaffected by halothane. Halothane moderately lowered the $\mathrm{P} / \mathrm{O}$ ratios of both the normal and the affected muscle.

Glutamate and malate state 3 respiration (Table X) varied inversely with the age of the patient. This effect was significantly more pronounced in the MH than in the control patients. The addition of increasing doses of halothane progressively inhibited this age dependence so that, at the two higher concentrations ( 1.8 per cent and 5.0 per cent), it had ceased to exist.

In the presence of succinate (Table XI) and the absence of halothane there were no statistical differences between the $\mathrm{Q}_{3}, \mathrm{Q}_{4}$, R.C.I. or $\mathrm{P} / \mathrm{O}$ values of the normal and the hyperthermic patients nor among the hyperthermic patients. Equilibration with halothane (Tables IX and XI) produced little alteration in these values except in the $\mathrm{P} / \mathrm{O}$ ratio which was slightly reduced.

These results are in essential agreement with those presented in a "work in progress" report ${ }^{137}$ on our first three hyperthermic patients and with our observations of the effect of potent inhalational agents on rat skeletal muscle. ${ }^{210}$ 


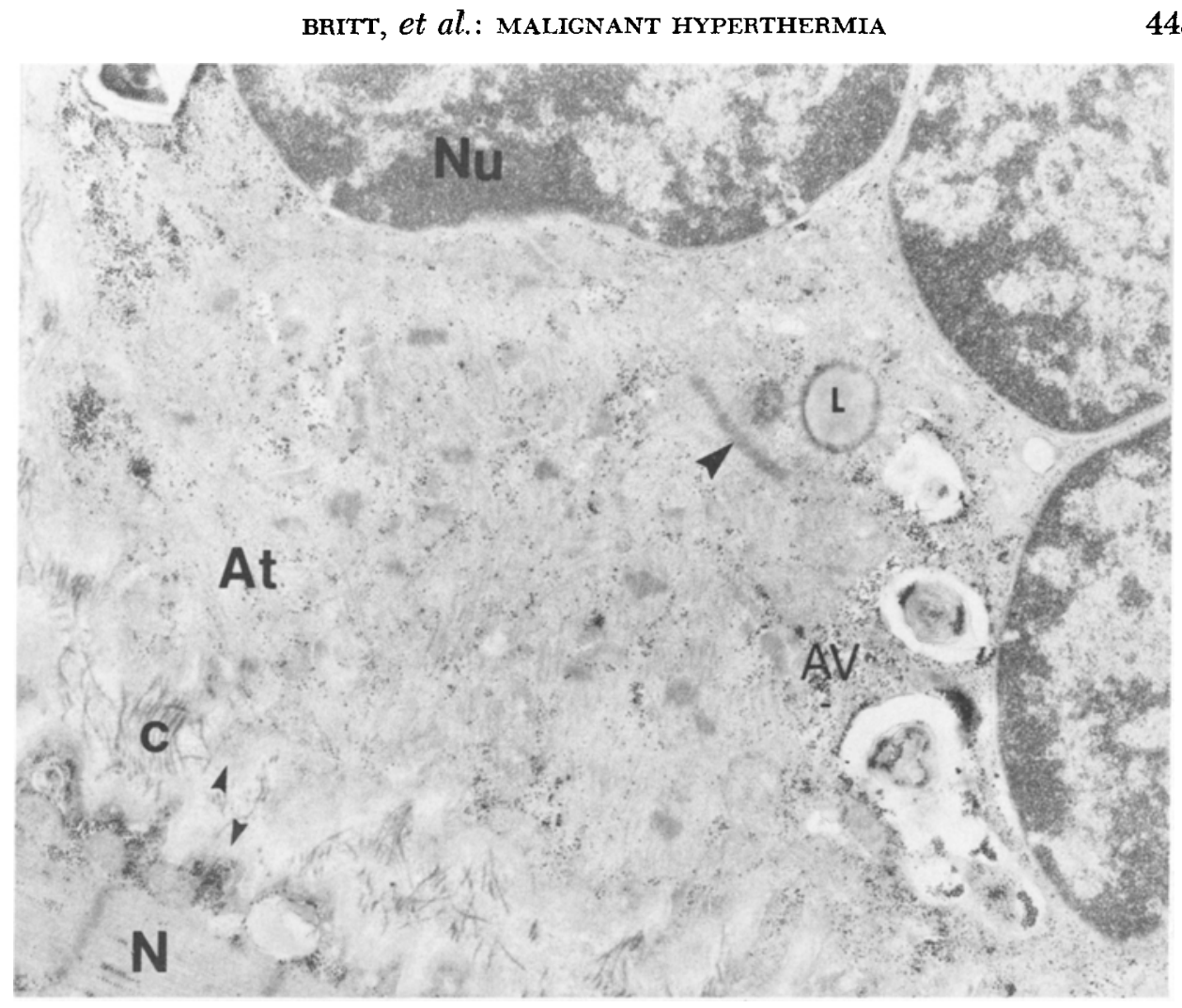

Figure 6. Parts of two fibres are depicted. At the bottom left is a normal fibre (N) separated from an atrophic fibre (At) by intervening collagen fibrils (c) between the respective basement membranes (small arrows). The atrophic fibre has several nuclei ( $\mathrm{Nu}$ ) and contains disorganized fibrillar material with Z-band material (large arrow), as well as a lipid body (L) and several autophagic vacuoles containing lamellated material (AB). Patient E.

Gluteraldehyde Fixation (VA/Pbk). Magnification ×8,400.

\section{Isometric Muscle Contraction}

Caffeine added to the bath of normal isolated muscle caused the muscle to contract. The contracture was potentiated by the addition of a 1.0 per cent halothane vapour to the carbogen bubbling through the bath. The results are summarized in Figures $9 \mathrm{~A}$ and $9 \mathrm{~B}$ in plots of caffeine concentration versus contracture expressed in grams of muscle tension. The shift of the family of curves to the left in Figure 9B as compared to Figure 9A, illustrates the potentiating action of the 1.0 per cent halothane.

The maximal caffeine contracture was reached in three or four minutes and persisted until the caffeine was washed out. The tension returned to baseline within five to seven minutes. Renewed addition of the same caffeine concentration always had effects which were indistinguishable from those produced by the first addition.

Halothane alone never caused contracture either at the usual bath temperature of $25^{\circ} \mathrm{C}$ or at $37^{\circ} \mathrm{C}$. Dose-effect curves for halothane in the presence of fixed concentrations of caffeine (which are not shown) usually had a maximum at 2 


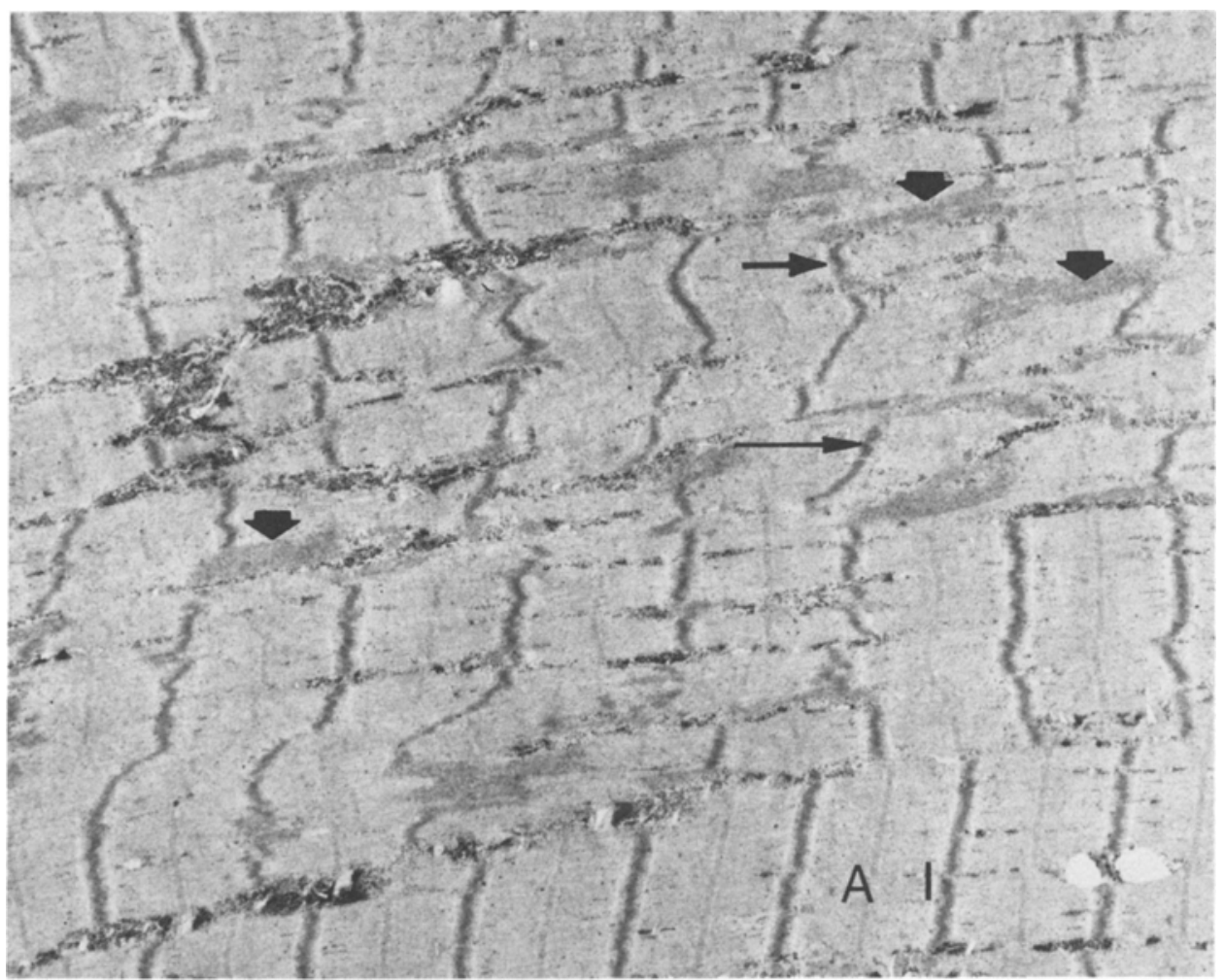

Figure 7. Normal $\mathrm{Z}$ lines (arrows) and $\mathrm{A}$ bands (A) are present but there is contracture of the $\mathrm{I}$ band making it less obvious. Streaming of $\mathrm{Z}$ line material across all or part of numerous sarcomeres is occurring representing early myofibrillar degeneration and possibly the earliest phase of targetoid change (thick arrows). Patient E.

Gluteraldehyde and osmium fixation. Magnification $\times 8,400$.

per cent halothane. Higher concentrations tended to have less effect, and 5 per cent damaged some preparations irreversibly.

Muscle from the five patients showed an increased susceptibility to caffeine contracture both in the presence and in the absence of halothane. That is, the MH muscles contracted at lower caffeine concentrations than control muscles.

When the dose-effect curves (Figures 9A and 9B) were used to determine for each muscle the caffeine concentration which increased the resting tension by $1 \mathrm{~g}$, the data could be subjected to statistical analysis. The geometric means of the caffeine concentrations for $\mathrm{MH}$ muscle and for all control specimens differed by a factor of 3.5 in the absence of halothane and by a factor of 5.0 in the presence of halothane. Each of these differences between $\mathrm{MH}$ and control muscles was statistically significant with $\mathrm{p}<0.01$. However, the difference between the factors 3.5 and 5 was statistically not significant; that is, there was no statistical support for the impression conveyed by the inspection of the curves that halothane enhanced the difference of caffeine sensitivity between MH and control muscle.

As described under "Methods," the control muscles used for this study were partly obtained from amputations required for cancer. The scatter of the control 


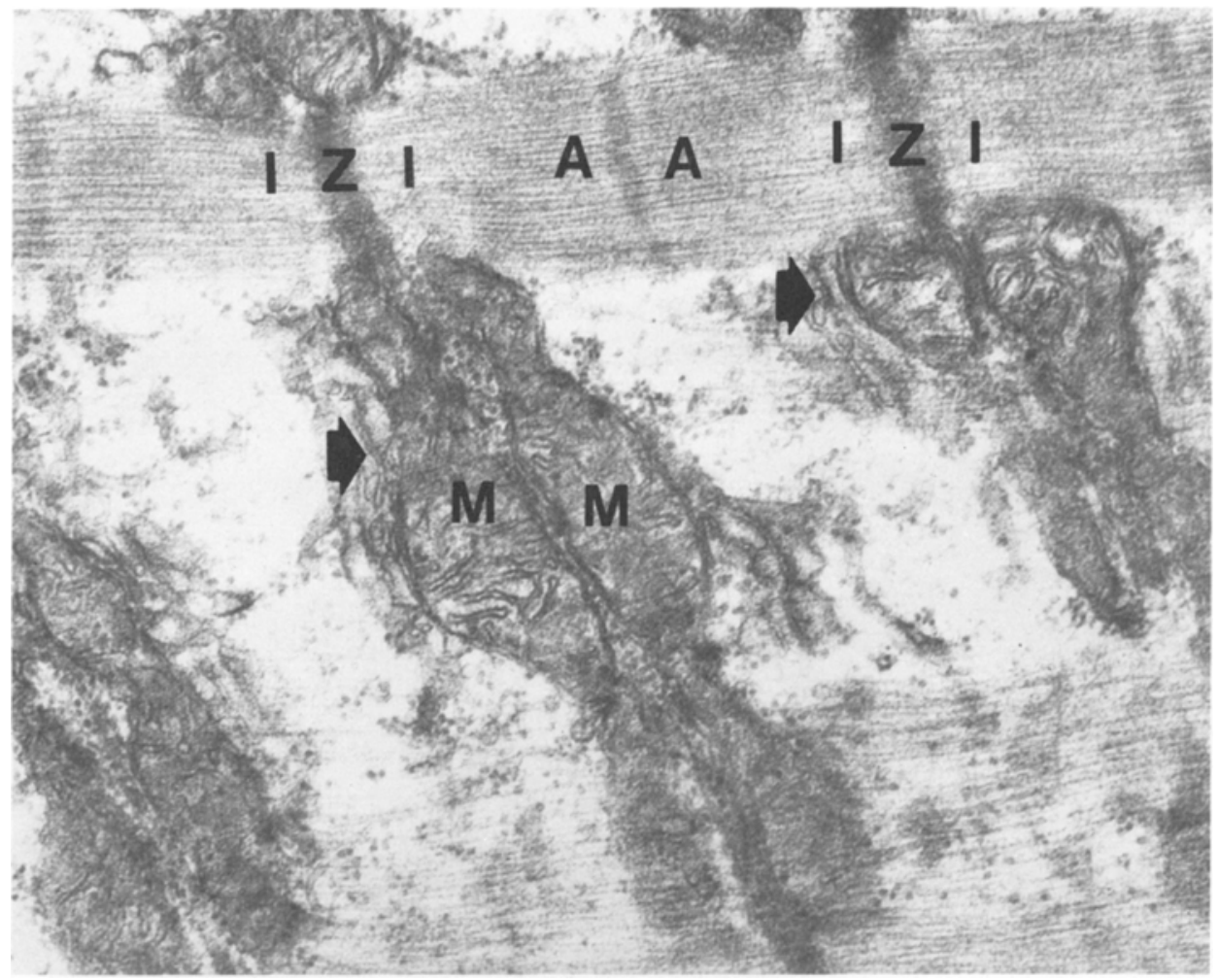

Frgure 8. At the top, the normal sarcomere structure is identified with $A$ band (A), I band (I) and $Z$ lines $(Z)$. Paired mitochondria $(M)$ are present at the level of the $Z$ line. Adjacent to the A-I junction are triads consisting of distinct transverse " $t$ " tubules (arrows) with less distinct lateral sacs of the endoplasmic reticulum on either side. These structures are all normal. Patient E.

Osmium-fixed VA, Pbk. Magnification $\times 38,000$.

muscle responses, therefore, did not necessarily reflect the variation encountered among healthy subjects.

The muscle specimen of patient D and several control muscles, were exposed to $10^{-4} \mathrm{M}$ succinylcholine. No effect ensued. In muscles of patients with myotonic disorders, succinylcholine causes a contracture under our experimental conditions.

\section{Sarcoplasmic Reticulum}

The data on calcium accumulation by isolated sarcoplasmic reticulum are shown in Table XII and in Figure 10 for patients A, B, C and E. Unfortunately, insufficient muscle was available to permit this study to be carried out on patient $\mathrm{D}$.

In the absence of halothane, calcium uptake into the sarcoplasmic reticulum was significantly greater on the average in the control than in the MH patients. For one individual MH patient (A), however, there was some overlapping with those control patients whose values were in the lower part of the normal range. 
TABLE IX

Comparison of Slopes (Against Halothane Concentration) from Normal and Malignant Hyperthermic Muscle Mitochondria

\begin{tabular}{|c|c|c|c|}
\hline & Control & $\begin{array}{l}\text { Malignant } \\
\text { Hyperthermia }\end{array}$ & $t(d . f .=27)$ \\
\hline $\begin{array}{l}\text { Glutamate + Malate } \\
\log _{10} Q_{3} \\
\log _{10} Q_{4} \\
\log _{10} \text { R.C.I. } \\
\text { P/O }\end{array}$ & $\begin{array}{l}-0.100 \pm 0.009 \dagger \\
0.002 \pm 0.008 \mathrm{n} . \mathrm{s} . \\
-0.102 \pm 0.009 \dagger \\
-0.130 \pm 0.014 \dagger\end{array}$ & $\begin{array}{l}-0.107 \pm 0.012 \dagger \\
0.002 \pm 0.010 \mathrm{n.s} . \\
-0.111 \pm 0.013 \dagger \\
-0.140 \pm 0.019 \dagger\end{array}$ & $\begin{array}{l}0.48 \text { n.s. } \\
0.02 \text { n.s. } \\
0.58 \text { n.s. } \\
0.44 \text { n.s. }\end{array}$ \\
\hline $\begin{array}{l}\text { Succinate } \\
\log _{10} \mathrm{Q}_{3} \\
\log _{10} \mathbb{Q}_{4} \\
\log _{10} \widetilde{R} \mathrm{C} . \mathrm{I} . \\
\mathrm{P} / \mathrm{O}\end{array}$ & $\begin{array}{r}-0.009 \pm 0.006 \text { n.s. } \\
-0.010 \pm 0.005 \text { n.s. } \\
0.005 \pm 0.004 \text { n.s. } \\
-0.039 \pm 0.007 \dagger\end{array}$ & $\begin{array}{r}0.009 \pm 0.008 \text { n.s. } \\
0.011 \pm 0.010 \text { n.s. } \\
-0.007 \pm 0.007 \text { n.s. } \\
-0.064 \pm 0.017^{*}\end{array}$ & $\begin{array}{l}1.77 \text { n.s. } \\
1.88 \text { n.s. } \\
1.40 \text { n.s. } \\
1.46 \text { n.s. }\end{array}$ \\
\hline
\end{tabular}

TABLE $X$

Age Dependence of State 3 Respiration in Control and Hyperthermic SUBJECTS

\begin{tabular}{cccccc}
\hline & & \multicolumn{2}{c}{ Slope* } & \multicolumn{2}{c}{$\begin{array}{c}\text { Test for Difference } \\
\text { Between Slopes }\end{array}$} \\
\cline { 2 - 5 } Halothane & Control & Hyperthermic & & $\mathbf{t}$ & D.F. \\
\hline 0 & $-2.43 \pm 0.68 \$$ & $-11.29 \pm 1.80 \$$ & & $4.57 \S$ & 45 \\
0.50 & $-1.15 \pm 1.40$ & $-8.85 \pm 2.22 \ddagger$ & & $2.94 \ddagger$ & 30 \\
1.83 & $-0.63 \pm 0.96$ & $-5.86 \pm 3.74$ & & 1.35 & 35 \\
5.0 & $0.59 \pm 2.17$ & $-1.43 \pm 4.64$ & & 0.23 & 34 \\
\hline
\end{tabular}

*1000 $\times$ slope of lines fitted in plots of $\log _{10} Q_{3}$ against age of subjects (in years). tVolume per cent halothane in air. $\ddagger \mathrm{P}<0.01$. $\S \mathrm{P}<0.001$.

In the normal patients 0.5 per cent and 2.0 per cent halothane accelerated calcium accumulation by the sarcoplasmic reticulum, while it was slightly inhibited by 5.0 per cent halothane. At all concentrations halothane lowered calcium uptake into the sarcoplasmic reticulum of all four $\mathrm{MH}$ patients. This effect was marked for A, B and E, but only moderate for C.

\section{Discussion}

\section{Blood Biochemical Studies (Table VII)}

The ideal management of malignant hyperthermia is detection of the condition prior to anaesthesia ${ }^{211,212}$ to enable complete avoidance of life threatening reactions. This may entail investigation of rather large numbers of individuals. Muscle biopsies or even electromyographs on such a large scale may not be practical. A simple reliable blood test would be much more desirable. Such does 


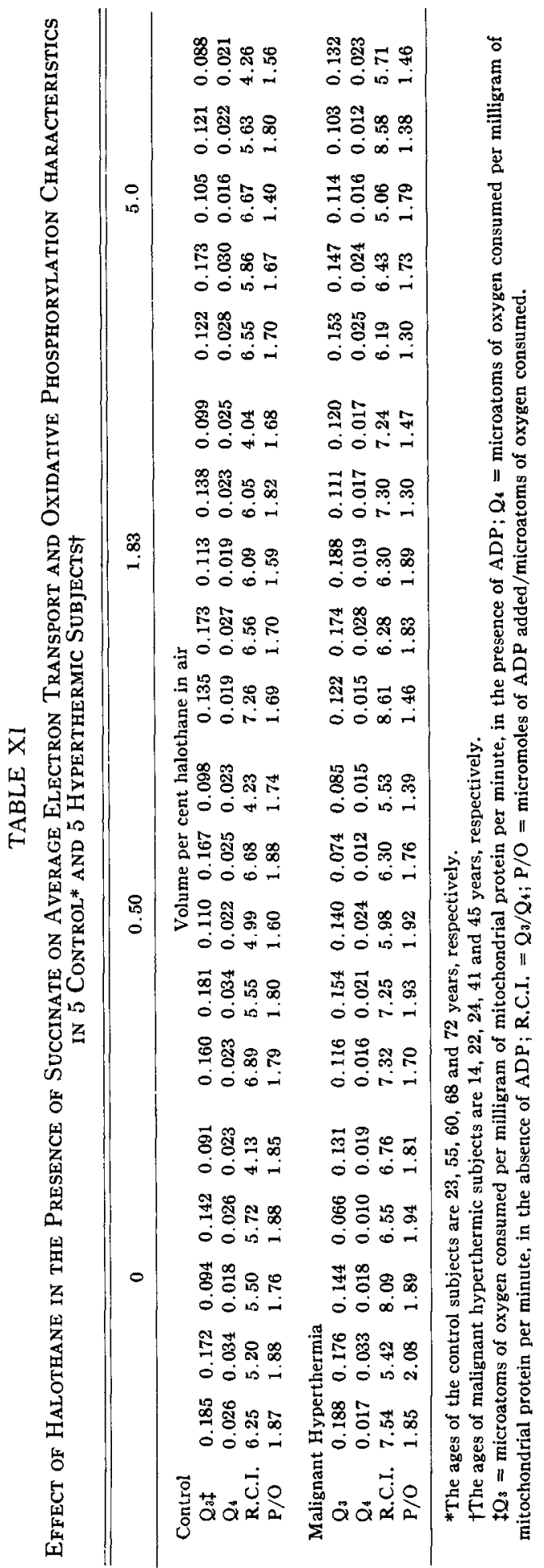




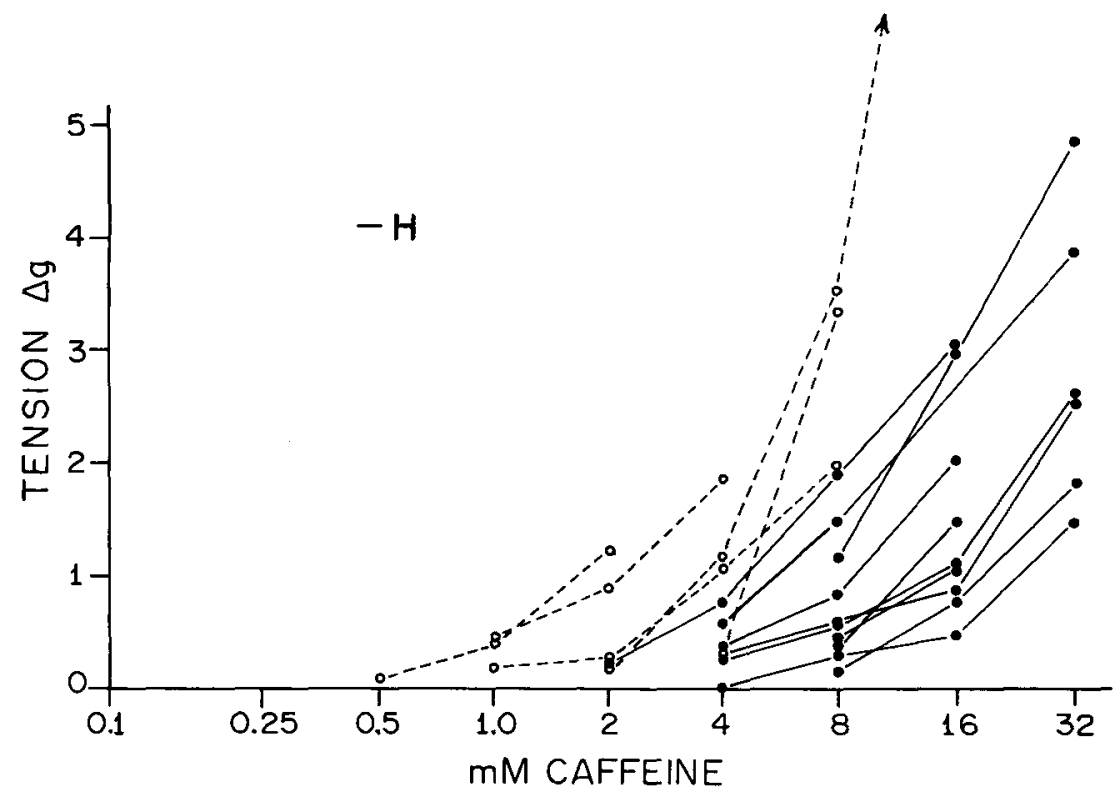

FIGURE 9A. Isolated muscle in the absence of halothane.

Caffeine contracture of isolated muscle from patients disposed to malignant hyperthermia and from controls. The abscissa indicates the concentration of caffeine in the tissue bath. The ordinate gives the increase of isometric contracture produced by caffeine. The plot shows the measurements obtained when no halothane was added to the oxygen/carbon-dioxide mixture bubbling through the bath.

- - $=$ control muscle.

$-\cdots---=$ patient's muscle.

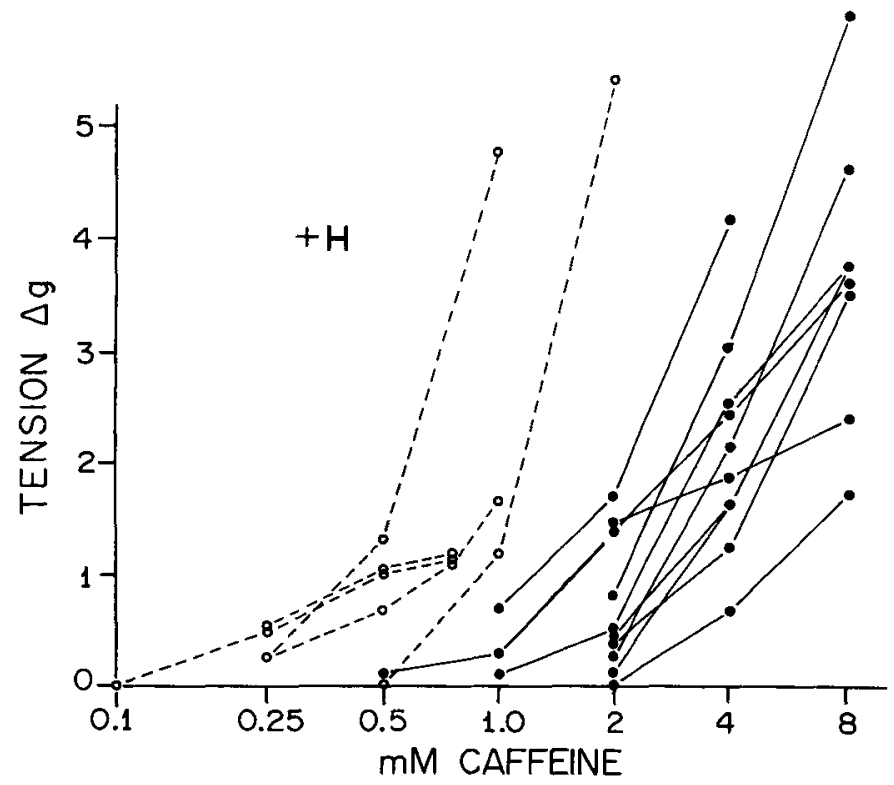

Figure 9B. Isomated muscle in the presence of 1.0 per cent halothane.

The plot shows the measurements obtained when 1 per cent halothane was added to the oxygen/carbon-dioxide mixture bubbling through the bath.

Legends and symbols as in $9 \mathrm{~B}$. 
TABLE XII

Values Represent Calcium Uptake into the Sarcoplasmic Reticulum Expressed as $\mathrm{mMCa}^{45} / \mathrm{mg}$ Protein/5 Minutes

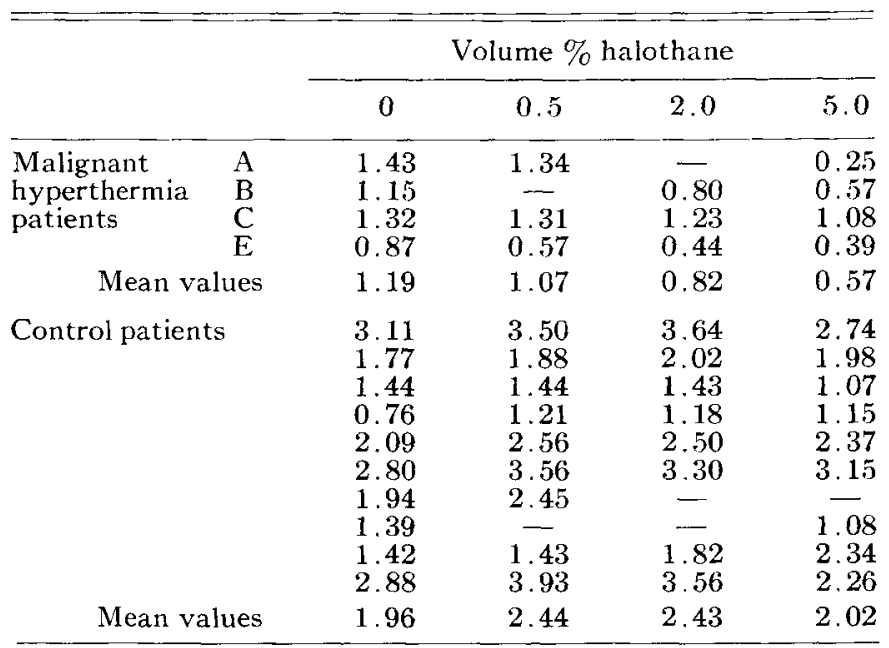

not yet appear to have been developed. A number of blood biochemical parameters (serum CPK, LDT, HBDH, GOT, $\mathrm{Ca}, \mathrm{Pi}, \mathrm{Mg}$, lactate and pyruvate) were measured in these patients on three successive occasions. With the exception of the serum enzymes and pyruvate levels, no abnormalities were observed. Serum magnesiums were at the lower limits of normal.

Plasma levels of CPK have been considered by Isaacs, ${ }^{108}$ Zsigmond, ${ }^{99}$ Denborough ${ }^{139}$ and others to be the best predictor of malignant hyperthermia. It was also in this series the best biochemical indicator, being markedly elevated before the biopsies in four of five patients. However, it is not reliable - volunteer $B$ having only a modest elevation in the first measurement and a normal level on the third measurement. These differences between affected subjects may be due to inherent differences in the severity or nature of the muscle defect, or to scondary environmental differences related to amount of prior physical exercise or degree of surgical trauma. As expected, the CPK values rose after the biopsies. No suitable control data are available to indicate whether or not the extent of rise was unusual.

If the CPK leaks across damaged membranes more readily than across intact membranes, ${ }^{213-220}$ the CPK elevations could indicate a muscle membrane defect in MH. The functional significance of such a membrane defect might be that the rate of CPK release into the blood is greater than normal when the muscle is subjected to such stresses as exercise or surgery. In the future, therefore, when suspected individuals have normal CPK measurements, it may be necessary to subject them to periods of standardized exercise and then to remeasure. A significantly greater than normal rise in the CPK following the exercise period would favour a presumptive diagnosis of malignant hyperthermia. 


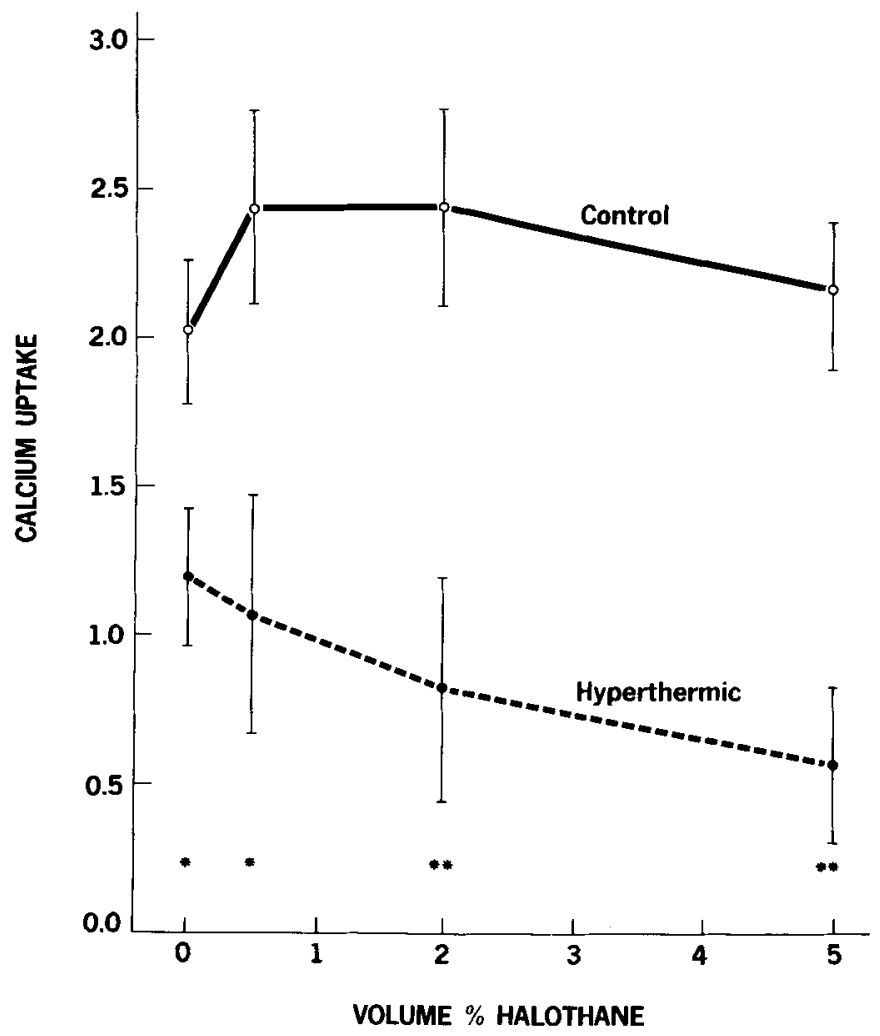

FiguRE 10. Abscissa indicates concentration of halothane expressed as volume percent added to a homogenate of sarcoplasmic reticulum. Ordinate indicates uptake into sarcoplasmic reticulum of $\mathrm{Ca}^{45} \mathrm{Cl}$ in $\mathrm{mM} / \mathrm{mg}$ protein during five minutes.

Zsigmond et al. ${ }^{99}$ have suggested that the source of plasma CPK in $\mathrm{MH}$, is brain.

Phosphate elevations were not seen in this series. High phosphate values have been detected in a few hyperthermic patients and some of their relatives. ${ }^{28}$ These people tend to have CPK levels which are either high normal, or only slightly elevated. Perhaps they represent a separate aetiological group.

The consistently low-normal values of serum magnesium seen in these patients have also been observed in other $\mathrm{MH}$ individuals measured by us. This deserves further study. MH may be characterized by a defect, not only of calcium storage, but also of magnesium storage since the rise in the serum calcium observed by Berman and his group ${ }^{111}$ in pigs undergoing a reaction was preceded by an increase of the serum magnesium.

Evidently the muscle cells of MH patients may have a slightly accelerated rate of glycolysis even prior to anaesthesia, as witness the moderately high pyruvate levels. It does not, however, appear to be so great as to significantly increase lactate production. A heightened glycolysis could be due to chronic but moderate 
activation of phosphorylase kinase by calcium ${ }^{221-223}$ or to increased demand for anaerobic ATP energy. The latter postulate appears unlikely, as all our patients exhibited normal basal metabolic rates.

\section{Electromyography}

Four of the five MH patients manifested non-specific abnormalities on electromyography in an increase in the number of polyphasic potentials. Similar findings have been reported by Steers et al., ${ }^{81}$ by La Cour and his workers ${ }^{147,148}$ and by Thompson and Tallack. ${ }^{188}$ Unlike La Cour' ${ }^{147,148}$ observation spontaneous activity was not seen in any of our patients. While our observations are suggestive they cannot be considered diagnostic of either neuropathy or myopathy.

\section{Microscopy}

All MH patients exhibited variability of fibre diameter with increased numbers of small fibres (Figures 1-4). In addition, in $A, D$ and $E$ the small angular fibres contained clumps of dark pyknotic nuclei and $\mathrm{D}$ and $\mathrm{E}$ manifested large round fibres up to 110 to $150 \mu$ in diameter. Such abnormalities have also been reported by Ellis et al..$^{141}$ and by Denborough et al. ${ }^{140}$

Denborough ${ }^{140}$ noted non-staining cores and Ellis ${ }^{141}$ observed fibres with a "moth-eaten" appearance on slides stained for oxidative enzymes. Such findings were not observed in any of our patients although patient $\mathrm{E}$ did display targetoid and target fibres (Figures 5, 7) and showed some Z-line streaming on electronmicroscopy (Figure 7). The ultrastructure of target and targetoid fibres bears close resemblance to that of cores and both abnormalities, as well as streaming of the Z-line, may represent different stages of severity of structural damage to the muscle fibre. Target cells are characteristic of neurogenic atrophy but may be found in some myopathies as well. Some authors ${ }^{224}$ consider denervation to be a possible cause of the cores in central core disease. It is of interest that patient $\mathrm{E}$ had fibrotic intramuscular nerves as well as target and targetoid fibres (Figure 5). $\mathrm{La}$ Cour ${ }^{147,148}$ has postulated that the primary defect of malignant hyperthermia resides in the peripheral nerve. Malignant hyperthermia is not the only muscle disease in which the merits of a neurogenic or a myogenic origin are being debated. The same question arises for several types of muscular dystrophy. ${ }^{225,226}$ For the present, the answer to this problem must remain speculative. Certainly there is little evidence, so far, for primary neurogenic involvement in our cases.

Electron microscopic study of three of the biopsies did not add any significant data to the light microscopy observations, showing only the ultrastructural counterpart of non-specific structural abnormalities. Tubular aggregates, myofibrillar disorganization, autophagic vacuoles and lipochrome are found in muscle fibres undergoing structural changes. From the negative point of view we could not demonstrate any abnormality in the appearance of mitochondria, " $\mathrm{T}$ " system, or sarcoplasmic reticulum (Figure 8), the organelles in which the MH defect might reside. However, it should be pointed out again that four of the five patients were studied many months after the episode and one patient (E) has never had an attack. The significance of the isolated focal areas of necrosis and macrophage 
response in two of the patients is unkown. They are definitely not the result of EMG needles or intramuscular injections. Perhaps they represent areas of active muscle breakdown due to the primary disorder.

The structural changes which we have described in the skeletal muscle of our five patients can in no way be regarded as unique to malignant hyperthermia. If a specific morphological abnormality is to be demonstrated as a component of this disorder, study of muscle during or immediately following an episode is imperative.

\section{Skeletal Muscle Mitochondria}

In the absence of halothane the hyperthermic mitochondria appear to be in a normal functional state with regard to their ability to produce ATP with a minimum expenditure of time, ADP, oxygen and heat. This is suggested by the fact that, like the normal mitochondria, they had electron transport systems which were tightly coupled to oxidative phosphorylation, as indicated by high R.C.I.s and $\mathrm{P} / \mathrm{O}$ ratios (Tables VIII, IX, XI). In fact, in terms of these latter two parameters, the hyperthermic mitochondria may be slightly better coupled than the normal mitochondria. Although the difference is not statistically significant on direct test the trend is nevertheless supported by the observation of a strong age dependence of the $Q_{3}$ (Table $X$ ). It has already been observed that the average age of the hyperthermic patients was considerably less than that of the control patients. On the other hand, it may perhaps be that in the in vivo state these mitochondria have had to compensate for some long term defect, such as moderately high cytoplasmic calcium, which would tend to cause some slight degree of uncoupling of mitochondria from control patients. Isolated in the in vitro state in a calcium free medium these $\mathrm{MH}$ mitochondria, now relieved of their high calcium environment, thus appear to be a little more efficiently coupled than normal.

A major action of halothane on both hyperthermic and normal mitochondria must be inhibition of electron transport since, in each, halothane produces a marked reduction of the NAD-linked $Q_{3}$ but has no effect on the NAD-linked $Q_{4}$ (Tables VIII, IX). The site of this inhibition of electron transport must be in the region of the first phosphorylation, i.e., in Complex $\mathbf{I}^{210,227-230}$ as halothane does not inhibit the NAD-linked, succinate $Q_{3}$, and has no significant effect on the NAD-linked $\mathrm{Q}_{4}$ (Tables IX, XI).

In both the normal and the hyperthermic mitochondria, the slight reduction in $\mathrm{P} / \mathrm{O}$ ratios and the failure of state 4 respiration to rise in the presence of halothane, label this anaesthetic as only a very weak uncoupler of oxidative phosphorylation.

The major action of halothane on the isolated hyperthermic mitochondria, therefore, appears to be inhibition of electron transport, with uncoupling of oxidative phosphorylation playing only a minor role. Slowing of electron transport lowers heat production and oxygen consumption. Conversely, uncoupling of oxidative phosphorylation raises both heat output and oxygen input. The net effect of halothane on the mitochondria is one of considerably reduced oxygen uptake and heat generation. 
We must conclude, therefore, that the alterations induced by halothane in isolated skeletal muscle mitochondria do not account for the fever and hypoxia of an acute malignant hyperpyrexial reaction and that the primary defect of malignant hyperthermia must lie elsewhere. However, this does not rule out a secondary uncoupling of muscle oxidative phosphorylation by halothane in the living patient undergoing an acute $\mathrm{MH}$ crisis. Uncoupling might be induced, for instance, by a marked rise in the sarcoplasmic calcium beyond the transporting capacity even of mitochondria adjusted over a long period to moderately elevated cytoplasmic calcium levels. A low myoplasmic magnesium would be expected to potentiate this uncoupling.

\section{Isolated Isometric Muscle Contracture}

The chief effect of caffeine upon an in vitro preparation of normal whole skeletal muscle is an increase in the concentration of the sarcoplasmic calcium $^{231,232}$ which is independent of the state of polarization of the muscle. This may be due to a primary acceleration in calcium release from the sarcoplasmic reticulum or intereference with calcium uptake into the sarcoplasmic reticulum. ${ }^{233,234}$ On the other hand, the primary event may be release of calcium from the sarcolemma and possibly the transverse tubules, or influx of extracellular calcium through the sarcolemma to the sarcoplasm. This "trigger" calcium would in turn secondarily generate the release of still more calcium from the sarcoplasmic reticulum.

Our findings (Figures $9 \mathrm{~A}$ and 9B) indicate that MH-sarcoplasmic reticulum has an impaired ability to retain calcium in the presence of caffeine or of caffeine and halothane. They are in essential agreement with those of Moulds and Denborough $^{149}$ and of Ellis ${ }^{141}$ although Ellis was able to induce a contracture in affected muscle with the administration of halothane alone without the addition of caffeine. This discrepancy may have been due to use of a medium with a different composition. Another difference is that Ellis used only muscle selected to include motor endplates, as determined by electrical stimulation of the exposed muscle prior to excision. However, in vitro exposures of our specimens to curare indicated that they were not free of end plates. Finally, Ellis kept his bathing medium at $37^{\circ} \mathrm{C}$, but we found that the use of this higher temperature did not influence our results.

In this study there was a clear cut difference between the normal and the $\mathrm{MH}$ patients, so that a diagnosis of malignant hyperthermia could be readily made from the values obtained for each individual muscle sample. As it requires only a small piece of muscle (about $1.5 \mathrm{gm}$ ), it may, therefore, become a useful diagnostic test for patients related to $\mathrm{MH}$ individuals whose crises have been characterized by rigidity. This would be especially so in those who have normal CPK levels, thus making diagnosis difficult. The isometric muscle contraction test does not appear to be so useful for non-rigid $\mathrm{MH}$ patients ${ }^{137.145}$ whose muscle appears to develop a normal contracture in the presence of caffeine or caffeine and halothane, similar in degree to that observed in control patients.

\section{Sarcoplasmic Reticulum}

The halothane-induced inhibition of calcium accumulation by the sarcoplasmic 
reticulum (Table XII, Figure 10) supports the hypothesis that human crises are precipitated by a rise in myoplasmic calcium concentration. ${ }^{145,154}$ These results are, however, at variance with those of most porcine studies. Berman and coworkers, ${ }^{120}$ Nelson et al., ${ }^{129}$ Steward and Thomas ${ }^{133}$ and Britt ${ }^{235}$ have all described normal or moderately augmented calcium uptake into porcine SR. Only Brucker et al..$^{122}$ and Denborough, Hird and colleagues ${ }^{123}$ have found that halothane inhibits the movement of calcium into porcine SR. These contradictory reports suggest some differences in aetiology between humans and some pigs and also among various swine herds. Definitive studies have not, however, been carried out to determine the influence of halothane on calcium release from hyperthermic SR. Until this has been shown to be normal, a primary calcium storing defect of hyperthermic SR cannot be entirely ruled out in those swine which have normal calcium movement into their SR.

\section{Conclusions}

The elevated serum levels of muscle enzymes, polyphasic muscle action potentials, and microscopic abnormalities, while not entirely consistent from case to case, indicate that a defect exists in the skeletal muscle of malignant hyperthermia (MH) patients. From the morphological study alone, the skeletal muscle changes are non-specific and do not allow us to indicate a primary muscle cell defect or a neuronal-mediated defect.

The most consistent abnormalities of $\mathrm{MH}$ muscle were variation of fibre diameter, an increased sensitivity to caffeine-induced contracture in vitro, and inhibition by halothane of the calcium storage capacity of the isolated sarcoplasmic reticulum. We therefore postulate that the biochemical nature of the defect seems to lie in a defective sarcoplasmic reticulum (SR) membrane which is not adequately able to accumulate calcium in the presence of anaesthetic agents such as halothane. The resulting excessively high myoplasmic calcium in turn: (1) activates phosphorylase kinase, ${ }^{221-223}$ thus accelerating glycolysis; (2) activates myosin ATPase, ${ }^{236-241}$ thereby accelerating hydrolysis of ATP to ADP, phosphate and heat; (3) inhibits troponin ${ }^{236-245}$ so permitting a contracture to occur; and (4) is taken up into the mitochondria where it induces secondary uncoupling of oxidative phosphorylation ${ }^{152,246-249}$ decreasing ATP production while stimulating heat and carbon dioxide output and oxygen consumption. Primary uncoupling of oxidative phosphorylation, however, does not appear to be a feature of $\mathrm{MH}$ in human patients as, in all cases examined, oxidative phosphorylation and electron transport of isolated sarcosomes were normal.

The several parameters which we investigated were not entirely uniform in all five patients. Other workers ${ }^{101,146,162}$ have also found clinical and laboratory differences among MH families. The rigid variant of malignant hyperpyrexia in man, therefore, may be a syndrome encompassing several biochemical aberrations.

In some families, malignant hyperthermia is never accompanied by rigidity and there are reasons to believe that the primary defect in these families is different from those in which rigidity can occur. It should be stressed that the present report is confined to malignant hyperthermia with rigidity. 


\section{RÉSUMÉ}

Les taux élevés dans le sérum d'enzymes musculaires, de potentiels d'action poly phasiques du muscle et la présence d'anomalies microscopiques, bien qu'elles varient d'un cas à l'autre, indiquent la présence d'un défaut dans le muscle squelettique des malades $\mathrm{MH}$. D'après l'étude morphologique seulement, les changements du muscle squelettique ne sont pas spécifiques et ne nous permettent pas d'indiquer un défaut primaire de la cellule musculaire ou un défaut neuronal intermédiaire.

Les anomalies les plus constantes du muscle des $\mathrm{M} \mathrm{H}$ consistaient en une variation du diamètre de la fibre, à une sensibilité accrue à la contraction induite par la caféine in vitro et à linhibition par l'halothane du pouvoir d'emmagasiner le calcium du réticulum sarcoplasmique isolé. En conséquence, nous avons postulé que la nature biochimique du défaut semble résider dans une membrane $S R$ défectueuse qui ne réussit pas entièrement à accumuler le calcium en présence des agents anesthésiques tel l'halothane.

Le taux excessivement élevé de calcium myoplasmique qui en résulte à son tour : (1) active la phosphorylase Kinase ${ }^{221,223}$ accélérant ainsi la glycolyse; (2) active la myosine ATPase ${ }^{236,241}$ accélérant ainsi l'hydrolyse de l'ATP en ADP, phosphates en chaleur; (3) inhibe la troponine ${ }^{236,245}$ permettant ainsi production de contracture et (4) il est capté dans les mitochondries où, secondairement, il provoque une dissociation de la phosphorylation oxydative $e^{152,246,249}$ diminuant la production d'ATP et stimulant la consommation d'oxygène et la production de $\mathrm{CO}_{2}$ et de chaleur. La dissociation primaire de la phosphorylation oxydative, toutefois, ne semble pas être un facteur chez les humains en hyperthermie maligne, car, dans tous les cas examines, la phosphorylation oxydative et le transport des électrons des sarcosomes isolés étaient normaux.

Les quelques paramètres que nous avons étudié ne se répétaient pas entièrement chez les cinq malades.

D'autres chercheurs ${ }^{101,146,162}$ ont également trouvé des différences cliniques et de laboratoire entre les familles des malades M.G. La variante rigide de l'hyperpyrexie maligne chez les humains, en conséquence, pourrait être un syndrome incluant plusieurs aberration biochimiques.

Dans certaines familles, l'hyperthermie maligne ne s'accompagne jamais de rigidité et il y a lieu de croire que, dans ces familles, le défaut primaire est différent de celui que l'on rencontre dans les familles où la rigidité apparait. Nous attirons l'attention sur le fait que le présent rapport se limite à l'hyperthermie maligne s'accompagnant de rigidité.

\section{ACKNOWLEDGMENTS}

The authors gratefully thank the following technicians for their helpful contributions to this study: Mrs. M. Terreau, Miss D. Millman, Mr. H. Fung, Mrs. R. Gallacher, Mrs. M. Liland and Mrs. M. Kandos.

We wish also to thank the following orthopaedic surgeons of the Toronto General Hospital: Dr. D.L. MacIntosh, Dr. J. Kostuik and Dr. J.D. Graham. 
This study was supported by Medical Research Council grant \#MA-2441, P.S.I. grant \#3-33326928, a grant-in-aid supported by the Muscular Dystrophy Association and a grant from The Women's Auxiliary of Toronto General Hospital.

\section{REFERENCES}

1. Denborough, M.A. \& Lovell, R.R.H. Anaesthetic deaths in a family. Lancet $i$ : 45 (1960).

2. GUEDEL, A.E. Postoperative hyperthermia. Inhalation Anaesthesia, 2nd ed., p. 110 (1951).

3. KALOW, W. Malignant hyperthermia. Proc. Roy. Soc. Med. 63: 178 (1970).

4. Kalow, W. \& Britr, B.A. Malignant Hyperthermia. The Pharmacology of Thermoregulation. Symp. San Francisco, 1972 (Karger, Basel, 1973).

5. Proceedings of the International Symposium on Malignant Hyperthermia (eds. Gordon, R.A., Britt, B.A., and Kalow, W.), Charles C. Thomas, Springfield (1973).

6. Symposium on Malignant Hyperthermia. Hiroshima J. Anaesth. 7: No. 2, 3 and 4 (1971).

7. Aldnete, J.A., Padfiexd, A., Solomons, C.C., \& Rubright, M.W. Possible predictive tests for malignant hyperthermia during anaesthesia. J.A.M.A. 215: 1465 (1971)

8. ARENS, J.R. \& MCKnNoN, W.M.P. Malignant hyperpyrexia during anaesthesia. J.A.M.A. 215: 919 (1971).

9. Auerbach, V.H., Digeorge, A.M., Mayer, B.W., Hayden, M., Carpenter, G.G., KrumPERMAN, L.W., \& Truter, R. Rhabdomyolysis and hyperpyrexia in children after administration of succinylcholine. In: International Symposium on Malignant Hyperthermia (ed. Gordon, Britt and Kalow), Charles C. Thomas, Springfield, p. 30 (1973).

10. Barlow, M.B. \& IsaAcs, H. Malignant hyperpyrexial deaths in a family. Reports of three cases. Brit. J. Anaesth. 42: $1072(1970)$.

11. Brautigam, K.H. \& Sexbold, R. Rehler and Gefahren: Hyperthermie durch Allgemeinanaesthesie. Der Anaesthesist 18: 338 (1969).

12. Britt, B.A. \& Gordon, R.A. Three cases of malignant hyperthermia with special consideration of management. Canad. Anaesth. Soc. J. 16: 99 (1969).

13. Brown, P.C. Hyperpyrexia and anaesthesia. Brit. Med. J. 2: 1526 (1954).

14. Bruckner, J.B., Gethmann, J.W., Bartels, M., \& Eberlein, H.J. Malignant Hyperpyrexie und allgemeine Muskelrigiditat unter Allgemeinnarkose. Praktische Anaesthesie und Wiederbelebung 5: 305 (1970).

15. Capizzi, L.S., PHILlips, O.C., \& Harkis, L.C. Malignant hyperthermia during anaesthesia. Anaesthesiology 31: 97 (1969).

16. W.A.C. - California. Comments on Case Report \#247. Am. Soc. of Anaesthesiologists Newsletter 26: 30 (1962).

17. Carpenter, G.G., Auerbach, V.H., DiGeorge, A.M., Mayer, B.W., \& Schutta, H.S. Rhabdomyolysis after routine administration of succinylcholine in children. The Society for Paediatric Research, April 29-30, p. 175 (1966).

18. CoDY, J.R. Muscle rigidity following administration of succinylcholine. Anaesthesiology 29: 159 (1968).

19. Crocker, D., Blum, H., Adams, J.G., \& Smith, R.M. Hyperthermia during anaesthesia. Anesth. Analg. 48: 789 (1969).

20. CuLLEN, W.G. Malignant hyperpyrexia during general anaesthesia: a report of two cases. Canad. Anaesth. Soc. J. 13: 437 (1966).

21. Curtin, M.F. Temperature and anaesthesia. Irish J. Med. Sci. 140: 133 (1971).

22. Daniels, J.C., Polayes, I.M., VILlar, R., \& Hehre, F.W. Malignant hyperthermia with disseminated intravascular coagulation during general anaesthesia: a case report. Anesth. Analg. 48: 877 (1969).

23. DaviEs, D.D. Hypertonic syndrome associated with suxamethonium administration. Brit. J. Anaesth. 42: 656 (1970).

24. Davies, L.E. \& Graves, H.B. Hyperpyrexia and death associated with general anaesthesia. Canad, Anaesth. Soc. J. 13:447 (1966).

25. Davies, R.M., Packer, K.J., \& Whitmarsh, V. Malignant hyperpyrexia: two case reports. Brit. J. Anaesth. 41: 703 (1969).

26. Denborough, M.A., Forster, J.F.A., Hudson, M.C., Carter, N.G., \& Zapf, P. Malignant hyperpyrexia - a serious, preventable complication of general anaesthesia. Australasian Congress of Anaesthesiology, Melbourne, Australia, p. 167 (1970). 
27. Drury, P.M.E. \& Gilbertson, A.A. Malignant hyperpyrexia and anaesthesia: two case reports. Brit. J. Anaesth. 42: 1021 (1970).

28. Edelist, G. Malignant hyperthermia - an ounce of prevention. Anesthesiology 34: 387 (1971).

29. Fujita, T. A case of malignant hyperthermia. Hiroshima J. Anesth. 7: 93 (1971).

30. Gibson, J.A. \& Gardiner, D.M. Malignant hypertonic hyperpyrexia syndrome. Canad. Anaesth. Soc. J. 16: 106 (1969).

31. Gjenstö, H. Maligne Hyperpyrexie durch Allgemeinanaesthesie mit möglicher verbindung zu primärer muskelkrankheit. Der Anaesthesist 20: 306 ( 1971).

32. Halevy, S. \& MARx, G.F. Hyperthermia during a second anesthesia. Anesthesiology 35: 444. (1971).

33. Hallen, B. \& Swensson, S.A. Hypertermi muskelspasm och metabolisk acidos vid generell anestesi. Särtryck vr Läkartidningen 64: 4687 (1967).

34. Hogg, C.E. Malignant hyperpyrexia. Int. Anesth. Clinies 10: 111 (1972).

35. Hogg, S. \& Renwick, W. Hyperpyrexia during anaesthesia. Canad. Anaesth. Soc. J. 13: 429 (1966).

36. Imabuchi, K., Yamamura, Y., Kikuchi, Y., Fujita, M., Hashimoto, A., \& Matsui, M. Experiences of two cases of malignant hyperthermia during anesthesia. Hiroshima J. Anesth. 7: 97 (1971).

37. James, O.F. Hyperpyrexia and hypertonia in anaesthesia. Med. J. Australia 57: 1154 $(1970)$.

38. Katsuya, H. Malignant hyperpyrexia: a case report. Jap. J. Anesthesiol. 44: 661 (1969).

39. KATz, D, Recurrent malignant hyperpyrexia during anaesthesia. Anesth. Analg. 49: 226 $(1970)$.

40. Kimura, M. \& Izena, Y. A case of hyperthermia during surgery. Hiroshima J. Anesth. 7: $132(1971)$.

41. Kitsuzi, N., Ishiguro, A., \& Ohdoshi, E. A case of malignant hyperpyrexia. Hiroshima J. Anesth. 7: 126 (1971).

42. Kondo, T. A case of malignant hyperpyrexia. Hiroshima J. Anesth. 7: 161 (1971).

43. Kubo, T., Horikawa, M., Ohtani, M., \& Morio, M. A case of the lower body palsy, which cased the lower body muscle rigidity and pyrexia by succinylcholine. Hiroshima J. Anesth. 7: 183 (1971).

44. Kyei-Mensah, K., Lochwood, R., Tyrell, J.H., \& WilletT, I.H. Malignant hyperpyrexia: a study of a family. Brit. J. Anaesth. 43:811 (1971).

45. Kyei-Mensah, K., Tyrell, J.H., \& Summer, D.W. Malignant hyperpyrexia. Proc. Roy. Soc. Med. 66: 636 (1973).

46. Larafd, D.G., Rice, C.P., Robinson, R.W., Spencer, R.W., \& Westhead, R.A. Malignant hyperthermia: a study of an affected family. Brit. J. Anaesth. 44: 93 (1972).

47. Lavore, G. Hyperpyrexia during general anaesthesia: a case report. Canad. Anaesth. Soc. J. 13: 441 (1966).

48. P.S.M. - Mass. Comment on Case Report \#247. Am. Soc. Anesthesiologists Newsletter 26: $10(1962)$.

49. Maruyama, M., Masuko, K., Kato, A., \& Ichryanagi, K. Malignant hypertonic hyperpyrexia accompanying halothane and ether anaesthesia. Hiroshima J. Anesth. 7: 61 (1971).

50. Manx, G.F. Malignant hyperthermia. Anaesthesiology 31: 585 (1969).

51. Mills, D.E. \& MARCY, J.H. Malignant hyperthermia with subsequent uneventful general anesthesia. Anesth. Analg. 50: 1104 (1971)

52. Miyata, T., Yogi, I., Matsuzuki, S., Ryu, S., Masuda, Y., Takao, K., Okamoto, M., \& Kimuria, M. Hyperpyrexia during anaesthesia and surgery. A case report. Hiroshima J. Anesth. 7: 167 (1971).

53. Mizota, H., Yard, H., \& Miyazima, I. Malignant hyperpyrexia. Hiroshima J. Anesth. 7: $85(1971)$.

54. Morikawa, S., Iwasaki, Y., \& Hirata, T. Two cases of familial malignant hyperpyrexia during general anesthesia in a family. Jap. J. Anesthesiol. 19: 895 (1970).

55. Morikawa, S. Malignant hyperpyrexia (mostly hereditary aspects). Hiroshima J. Anesth. $7: 43(1971)$.

56. Murray, B.R.P. \& Williams, P.A.D. Malignant hyperpyrexia during anaesthesia for colectomy. Brit. Med. J. 1: 488 (1969).

57. Ohtami, M., Nishino, K., Katayama, S., \& Morio, M. A case of malignant hyperpyrexia during anaesthesia. Hiroshima J. Anesth. 7: 153 (1971).

58. OJima, T., Takamatsu, O., Henmi, M., \& Honda, M. A case of abnormal hyperpyrexia developing during anesthesia. Hiroshima J. Anesth. 7:67 (1971). 
59. Окамото, T. Malignant hyperpyrexia - a case report. Hiroshima J. Anesth. 7: 123 (1971).

60. Opermann, Ch., Podlesch, I., \& Purschke, R. Maligne Hyperthermie wahrend Allgemeinanaesthesie mit Rigor, Myoglobinurie und Gerrinnungsstorung. Des Anaesthesist 20: 315 ( 1971 ).

61. Parikir, R.K. \& Thomson, W.H.S. Malignant hyperthermia: a fatal case and his family. Brit. J. Anaesth. 44: 742 (1972).

62. Pollock, R.A. \& Watson, R.L. Malignant hyperthermia associated with hypocalcaemia. Anesthesiology 34: 188 (1971).

63. Purkis, I.E., Horrelt, O., De Young, G., Fleming, R.A.P., \& Langley, G.R. Hyperpyrexia following anaesthesia in a second member of a family, with associated coagulation defect. Canad. Anaesth. Soc. J. 14: 183 (1967).

64. Quinn, J.R., Spatz, S.S., Shensa, D.R., \& Esway, J.K. Malignant hyperthermia during an oral surgical procedure: report of a case. J. Oral Surg. 27: 266 (1969).

65. RatzlafF, E.H. \& Jenkins, L.C. Malignant hyperthermia: a case report of successful management. Canad. Anaesth. Soc. J. 19: 549 (1972).

66. Relton, J.E.S., Creighton, R.E., Johnston, A.E., Pelton, D.A., \& Conn, A.W. Hyperpyrexia in association with general anaesthesia in children. Canad. Anaesth. Soc. J. 13: 419 (1966).

67. Relton, J.E.S., Creighton, R.E., Conn, A.W., \& Nabeto, S. Generalized muscular hypertonicity associated with general anaesthesia: a suggested anaesthetic management. Canad. Anaesth. Soc. J. 14: 22 (1967).

68. Relton, J.E.S., Creighton, R.E., \& ConN, A.W. Fulminant hyperpyrexia associated with anaesthesia. Anaesthesia 23: 253 (1968).

69. Reske-Nielsen, E. \& Kratholm, S. Malignant hyperthermia - a fatal case provoked by anaesthesia in asymptomatic encephalitis. Acta Anaesth. Scandinav. 15: 319 (1971).

70. Roweld, R.R. Malignant hyperthermia. Arch. Ophthal. 85: 638 (1971).

71. Ruttle, L.D. Case report \#247 - Death occurred in the operating room following extreme hyperthermia during an elective cholecystectomy. Am. Soc. Anaesthesiologists Newsletter 26:21 (1962).

72. Ryan, J.F. \& Papper, E.M. Malignant fever during and following anaesthesia. Anesthesiology 32: 196 (1970).

73. Saidman, L.J., Havard, E.S., \& EgER, E.I. Hyperthermia during anaesthesia. J.A.M.A. 190: 1029 (1964).

74. Satnick, J.H. Hyperthermia under anaesthesia with regional muscle flaccidity. Anesthesiology 30: 472 ( 1969).

75. SCHMm, E. \& ALDER, A. Anaesthesie-induzierte maligne hyperthermie. Der Anaesthesist 20: $310(1971)$.

76. Schweizer, O., Howland, W.S., Ryan, G.M., \& Goldiner, P.L. Hyperpyrexia in the operative and immediate post-operative field. Anesth. Analg. 50: 906 (1971).

77. Shibata, M., Sakai, Y., Tanaka, I., \& Shma, C. A case considered to be malignant hyperpyrexia. Hiroshima J. Anesth. 7: 129 (1971).

78. SNow, J.C. Malignant hyperpyrexia. E.E.N.T. Monthly 49: 427 (1970).

79. SNow, J.C. Malignant hyperthermia during anaesthesia and surgery. Arch. Ophthalmology 84: 407 (1970).

80. Soderberg, M.J. Anaesthesia and malignant hyperpyrexia. J. Am. Nurse Anaesthetists, p. 368 (Oct. 1969).

81. Steers, A.J.W., Tallack, J.A., \& Thompson, D.E.A. Fulminating hyperpyrexia during anaesthesia in a member of a myopathic family. Brit. Med. J. 2: 341 (1970).

82. StePheN, C.R. Fulminant hyperthermia during anaesthesia and surgery. J.A.M.A. 202: $178(1967)$.

83. Stovner, J., Gjengsto, H., \& Innes, R. Anestesiindusert Malign Hyperthermi i Norge. Saertrykk av Tidsskrift for Den norske Laegeforening 18: 1256 (1972).

84. Takenaka, M, \& IUchi, Y. A case of malignant hyperpyrexia. Hiroshima J. Anesth. 7: $120(1971)$.

85. Tanahashi, J., Uematu, H., Itokazu, M., Watanabe, K., Sano, S., \& Ito, M. Hyperpyrexia - a case report. Hiroshima J. Anesth. 7: 57 (1971).

86. Terasaki, H., Kuba, T., \& MoniokA, T. Malignant hyperpyrexia observed in a case of idiopathic scoliosis. Hiroshima J. Anesth. 7: 49 (1971).

87. Thomford, N.R., Hamelberg, W.E., \& Wiederholt, W.C. Sudden hyperpyrexia during general anaesthesia. Surgery 66: 850 (1969).

88. Thut, W.H. \& Davenport, H.T. Hyperpyrexia associated with succinylcholine-induced muscle rigidity: a case report. Canad. Anaesth. Soc. J. 13: 425 (1966). 
89. Toвias, M.A. \& Miller, C.G. Malignant hypertonic hyperpyrexia. Anaesthesia 25: 253 (1970).

90. TonogI, I. \& ITo, T. A case of malignant hyperpyrexia. Hiroshima J. Anesth. 7: 165 (1971).

91. Tonsa, A. \& Brücke, H. Maligne hyperthermie mit muskelrigidität in Narkose. Der Anaesthesist 20:312 (1971).

92. Tutrle, J.P. Heat stroke as a post-operative complication. J.A.M.A. 35: 1900 (1969).

93. Wakusawa, R., Shibata, S., Tiba, T., Hosoi, N., \& OKada, K. A case of malignant hyperpyrexia. Hiroshima J. Anesth. 7: 73 (1971).

94. WeILle, F. Malignant hyperthermia complicating general anaesthesia. Arch. Otolaryng. 90: $131(1969)$.

95. WILson, R.D., Dent, T.E., Traber, D.L., McCoy, N.R., \& Allen, C.R. Malignant hyperpyrexia with anaesthesia. J.A.M.A. 202: 183 (1967).

96. Winckier, C., Gréco, J., Bazin, G., \& Echinard, K. A propos d'un cas d'Hyperthermie maligne sous anesthésie générale. Société Française D'Anesthésie, D'Analgésie et de Réanimation.

97. YamaGuchi, K., Mori, R., Ushizima, K., \& IKezini, T. Two cases of hyperthermia developing during general anaesthesia. Hiroshima J. Anesth. 7: 79 (1971).

98. Yamazakt, Y., NAKazaki, K., Sekimoto, T., Sugawara, S., \& Tanaka, H. Malignant hyperpyrexia during anaesthesia - a case report. Hiroshima J. Anaesth. 7: 103 (1971).

99. Zsigmond, E.K., Starkweather, W.H., Duboff, G.S., \& FlynN, K. CPK and malignant hyperthermia. Anesth. Analg. 51:220 (1972).

100. BritT, B.A. \& Kalow, W. Hyperrigidity and hyperthermia associated with anaesthesia. Ann. N.Y. Acad. Sci. 151: 947 (1967).

101. Britr, B.A. \& KALow, W. Malignant hyperthermia: a statistical review. Canad. Anaesth. Soc. J. 17: 293 (1970).

102. Gjengsto, H. Die maligne hyperpyrexie: eine ernsthafte narkosekomplikation. Der Anaesthesist 20: 299 (1971).

103. BRown, L.L. Malignant hyperthermia: a case report. J. Med. Soc. South Carolina (in press).

104. BRITt, B.A., LOCHER, W.G., \& Kalow, W. Hereditary aspects of malignant hyperthermia. Canad. Anaesth. Soc. J. 16: 89 (1969).

105. Denborough, M.A., Forster, J.F.A., Lovelt, R.R.H., Maplestone, P.A., \& Villiers, J.D. Anaesthetic deaths in a family. Brit. J. Anaesth. 34: 395 (1962).

106. Denborough, M.A., King, J.O., Ebeling, P., \& ZAPF, P. Myopathy and malignant hyperpyrexia. Lancet $i$ : 1138 (1970).

107. IsAaCs, H. \& BARLow, M.B. Malignant hyperpyrexia during anaesthesia: possible association with subclinical myopathy. Brit. Med. J. 1: 275 (1970).

108. IsAACS, H. \& BARLOW, M.B. The genetic background to malignant hyperpyrexia revealed by serum creatine phosphokinase estimations in asymptomatic relatives. Brit. J. Anaesth. 42: 1077 (1970).

109. IsAACS, H. High serum creatine phosphokinase levels in asymptomatic members of the families of patients developing malignant hyperthermia - a genetic study. International Symposium on Malignant Hyperthermia (ed. Gordon, Britt and Kalow), Charles C. Thomas, Springfield, p. 331 (1973).

110. Allan, W.M., Berretr, S., Harding, J.D.J., \& Patterson, D.S.P. Plasma levels of muscle enzymes in the Pietrain pig in relation to the acute stress syndrome. The Veterinary Record 87: 410 (1970).

111. Berman, M.C., Harrison, G.G., Bulx, A.B., \& Kench, J.E. Changes underlying halothane-induced malignant hyperpyrexia in landrace pigs. Nature 225: 653 (1970).

112. Chalstry, L.J. \& EDward, G.B. Fatal hyperpyrexia following the use of pancuronium bromide in the pig. Brit. J. Anaesth. 44: 91 (1972).

113. Hall, L.W., WoolF, N., Bradley, J.W.P., \& Jolly, D.W. Unusual reaction to suxamethonium chloride. Brit. Med. J. 4: 1305 (1966).

114. HARRison, G.G. Anaesthetic-induced malignant hyperpyrexia: a suggested method of treatment. Brit. Med. J. 3: 454 ( 1971 ).

115. Harrison, G.G., Biebuyck, J.F., Terblanche, J., Dent, D.M., Hickman, R., \& Saunders, S.J. Hyperpyrexia during anaesthesia. Brit. Med. J. 3: 594 (1968).

116. Harkison, G.G., Saunders, S.J., Buebuyck, J.F., Hickman, R., Dent, D.M., Weaver, V., \& Terblanche, J. Anaesthetic-induced malignant hyperpyrexia and a method for its prediction. Brit. J. Anaesth. 41: 844 (1969).

117. Jones, W.E., KerR, D.D., \& NeLson, T.E. Malignant hyperthermia - observations in 
Poland China pigs. In: International Symposium on Malignant Hyperthermia (ed. Gordon, Britt and Kalow), Charles C. Thomas, Springfield, p. 198 (1973).

118. Jones, E.W., Nelson, T.E., \& Anderson, I.L. Malignant hyperthermia of swine. Anesthesiology 36: 42 (1972).

119. Woolf, N., Hall, L., Thorne, C., \& Down, M. Serum creatine phosphokinase levels in pigs reacting abnormally to halogenated anaesthetics. Brit. Med. J. 3: 386 (1970).

120. Berman, M.C. \& Kench, J.E. Biochemical features of malignant hyperthermia in landrace pigs. In: International Symposium on Malignant Hyperthermia (ed. Gordon, Britt and Kalow), Charles C. Thomas, Springfield, p. 287 (1973).

121. Lister, D. Correction of adverse response to suxamethonium of susceptible pigs. Brit. Med. J. 1: 208 (1972).

122. Brucker, R.F., Williams, C.H., Popinigis, J., Galvez, T.L., Vail, W.J., \& Taylor, C.A In vitro studies on liver mitochondria and skeletal muscle sarcoplasmic reticulum fragments isolated from hyperpyrexic swine. In: International Symposium on Malignant Hyperthermia (ed. Gordon, Britt and Kalow), Charles C. Thomas, p. 238 (1973).

123. Denborough, M.A., HIrd, F.J.R., King, J.O., Marginson, M.A., Mitchelson, K.R., Nayler, W.G., Rex, M.A., ZAPF, P., \& Condron, R.J. Mitochondrial and other studies in Australian landrace pigs affected with malignant hyperthermia. In: International Symposium on Malignant Hyperthermia (ed. Gordon, Britt and Kalow), Charles C. Thomas, Springfield, p. 229 (1973).

124. Hall, L.W., TrIm, C.M., \& Woolf, N. Further studies of porcine malignant hyperthermia. Brit. Med. J. 2: 145 (1972)

125. Harrison, G.G., Saunders, S.J., Biebuyck, J.F., Hickman, R., Dent, D.M., Weaver, V., \& Terblanche, J. Anaesthetic-induced malignant hyperpyrexia and a method for its prediction. Brit. J. Anaesth. 41: 844 (1969).

126. Harrison, G.G. Anaesthetic-induced malignant hyperthermia: a suggested method of treatment. Brit. Med. J. 3: 454 ( 1971).

127. Haraison, G.G. The effect of procaine and curare on the initiation of anaestheticinduced malignant hyperpyrexia. In: International Symposium on Malignant Hyperthermia (ed. Gordon, Britt and Kalow), Charles C. Thomas, Springfield, p. 271 (1973).

128. Kerr, D.D., Jones, E.W., Nelson, T.E., \& Gatz, E.E. Treatment of malignant hyperthermia in swine. Anesth. Analg. (in press, 1973).

129. Nelson, T.E., Jones, E.W., Venable, J.H., \& KerR, D.D. Malignant hyperthermia of Poland-China swine. Studies of a nyogenic etiology. Anesthesiology 36: 52 (1972).

130. Nelson, T. Procine malignant hyperthermia. Actions of muscle relaxants. Anesth. Analg. (in press, 1973).

131. Nelson, T. Malignant hyperthermia! sarcolemmal defect? Canad. Anaesth. Soc. J. (in press ).

132. Pollock, R.A., Standefer, J.C., Hildebrandt, P.K., Goodwin, B., \& Li, T-K. Malignant hyperthermia in the American landrace pig. In: International Symposium on Malignant Hyperthermia (ed. Gordon, Britt and Kalow), Charles C. Thomas, Springfield, p. 224 (1973).

133. Stewand, D.J. \& Thomas, T.A. Intracellular calcium metabolism and malignant hyperpyrexia. In: International Symposium on Malignant Hyperthermia (ed. Gordon, Britt and Kalow), Charles C. Thomas, Springfield, p. 409 ( 1973 ).

134. Venable, J.H. Skeletal muscle structure in Poland China pigs suffering from malignant hyperthermia. In: International Symposium on Malignant Hyperthermia (ed. Gordon, Britt and Kalow), Charles C. Thomas, Springfield, p. 208 ( 1973).

135. Bradley, W.G. \& Murchison, D. Screening for malignant hyperpyrexia. Brit. Med. J. 4: 108 (1972).

136. Bradley, W.G., Ward, M., Murchison, D., et al. Electrophysiological and pathological studies on malignant hyperpyrexia. Proc. Roy. Soc. Med. 67: 14 ( 1973).

137. Britr, B.A. Malignant hyperthermia - an investigation of three patients. Ann. Roy. Coll. Surgeons of Eng. 48: 73 (1971).

138. Brit, B.A., Kalow, W., \& EndRenYI, L. Malignant hyperthermia and the mitochondria in human patients. In: International Symposium on Malignant Hyperthermia (ed. Gordon, Britt and Kalow), Charles C. Thomas, Springfield, p. 387 (1973).

139. Denborough, M.A., Hudson, M.C., Forster, J.F.A., Carter, N.G., \& Zapf, P. Biochemical changes in malignant hyperthermia. Lancet $1: 1137$ (1970).

140. Denborough, M.A., Dennetr, X., \& Anderson, R.M.D. Central core disease and malignant hyperpyrexia. Brit. Med. J. 1: 272 (1973).

141. Ellis, F.R., Keaney, N.P., Hariman, D.G., Sumner, D.W., Kyei-Mensah, K., Tyrrel., 
J.H., Hargreaves, J.B., Parikh, R.K., \& Mulrooney, P.L. Screening for malignant hyperpyrexia. Brit. Med. J. 3: 559 (1972).

142. Ellis, F.R. Pathology of malignant hyperpyrexia. Brit. Med. J. $1: 249$ (1973).

143. Ellis, F.R., Keanex, N.P., \& Hariman, D.G.F. Histopathological and neuropharmacological aspects of malignant hyperpyrexia. Proc. Roy. Soc. Med. 66: 66 (1973).

144. IsaAcs, H. High serum creatine phosphokinase levels in asymptomatic members of the families of patients developing malignant hyperpyrexia - a genetic study. In: International Symposium on Malignant Hyperthermia (ed. Gordon, Britt and Kalow), Charles C. Thomas, Springfield, p. 331 ( 1973 ).

145. Kalow, W., Britt, B.A., Terreau, M.E., \& Haist, C. Metabolic error of muscle metabolism after recovery from malignant hyperthermia. Lancet $i i: 895$ (1970).

146. King, J.O., Denbonough, M.A., \& ZAPF, P.W. Inheritance of malignant hyperpyrexia. Lancet, $i: 365$ (1972).

147. LaCour, D., Juul-Jensen, P., \& Reske-Nielsen, E. Central and peripheral mechanisms in malignant hyperthermia. In: International Symposium on Malignant Hyperthermia (ed. Gordon, Britt and Kalow), Charles C. Thomas, Springfield, p. 380 (1973).

148. LaCour, D., Juul-Jensen, P., \& Reske-Nielsen, E. Malignant hyperthermia during anaesthesia. A neurophysiological and neuropathological follow-up study of a patient and his family. Acta Anaesth. Scand. 15: 299 (1971).

149. Moulds, R.F.W. \& Denborough, M.A. Procaine in malignant hyperpyrexia. Brit. Med. J. 4: 526 (1972).

150. Solomons, C.C. \& MYers, C.N. Hyperthermia of osteogenesis imperfects and its relationship to malignant hyperthermia. In: International Symposium on Malignant Hyperthermia (ed. Gordon, Britt and Kalow), Charles C. Thomas, Springfield, p. 319 (1973).

151. Starkweather, W.H., Zsigmond, E.K., Duboff, G.S., \& FlynN, K. Creatine phosphokinase isoenzyme patterns in a malignant hyperthermic family. In: International Symposium on Malignant Hyperthermia (ed. Gordon, Britt and Kalow), Charles C. Thomas, Springfield, p. 339 (1973).

152. BIANCHI, C.P. Cell calcium and malignant hyperthermia. In: International Symposium on Malignant Hyperthermia (ed. Gordon, Britt and Kalow), Charles C. Thomas, Springfield, p. 147 (1973).

153. BLOCH, M. Fulminating hyperthermia in general anaesthesia. Brit. Med. J. 1: 183 (1969).

154. BRITt, B.A. \& Kalow, W. Malignant hyperthermia: aetiology unknown! Canad. Anaesth. Soc. J. 17: 316 (1970).

155. Britr, B.A. Malignant hyperthermia - a brief review. Ontario Medical Review, Sept.Oct. p. 343 (1972).

156. BRIT, B.A. Recent advances in malignant hyperthermia. Anesth. Analg. 51: 841 (1972).

157. Churchill-Davmson, W. Malignant hyperpyrexia. Brit. Med. J. 3: 69 (1968).

158. Denborough, M.A., Hird, F.J.R., \& King, J.O. Correspondence - malignant hyperpyrexia. Brit. Med. J. 3: 636 (1971).

159. Morio, M. \& KodAma, G. Ether convulsion and malignant hyperthermia during anaesthesia. Hiroshima J. Anesth. 7: 135 (1971).

160. Epstein, R.M. Anesthesia and molecular diseases. 6th Ann. Seminar, Miami Beach, Florida, p. 27 (1969).

161. Furniss, P. Hyperpyrexia during anaesthesia. Brit. Med. J., 4: 745 (1970).

162. Funniss, P. The etiology of malignant hyperpyrexia (Abridged). Proc. Roy. Soc. Med. 64: 216 (1971).

163. Ohtani, M., Nakamura, T., Tanaka, A. et al. The change of body temperature during anaesthesia. Hiroshima J. Anesth. 7: 41 (1971).

164. GATz, E.E. \& JonEs, J.R. Haloperidol antagonism to the hyperpyrexic and lethal effects of 2,4-dinitrophenol in rats. Anesth. Analg. 49: 773 (1970).

165. GATZ, E.E. The mechanism of induction of malignant hyperpyrexia based on in vitro to in vivo correlative studies. In: International Symposium on Malignant Hyperthermia (ed. Gordon, Britt and Kalow), Charles C. Thomas, Springfield, p. 399 (1973).

166. Gatz, E.E., Schoettger, J.D., Morgan, J.R., Brrd, J.S., \& Jones, J.R. Etiology and control of malignant hyperpyrexia. Fed. Proc. 30: 341 (1971).

167. Gatz, E.E., Hult, M.J., BennetT, W.G., \& Jones, J.R. Effects of pentobarbital upon 2,4-dinitrophenol-induced hyperpyrexia during halothane anaesthesia. Fed. Proc. 29: $356(1970)$.

168. Gordon, R.A. Malignant hyperpyrexia during general anaesthesia. Canad. Anaesth. Soc. J. 13: 415 (1966). 
169. Новсн, G.P. \& Jones, G.O. State of contracture in malignant hyperthermia. Anesthesiology 35: 231 (1971).

170. HoRSEY, P.J. Hyperpyrexia during anaesthesia. Brit. Med. J. 3: 803 (1968).

171. Hull, M.J., Webster, W.W., \& Gatz, E.E. The effects of pentobarbital on 2,4-dinitrophenol-induced malignant hyperthermia during halothane general anesthesia in dogs. J. Oral Surgery 29: 640 (1971).

172. MCCAuL, K. Malignant hyperpyrexia during anaesthesia. Brit. J. Anaesth. 41: 562 (1969).

173. Pollock, R.A. \& Watson, R.L. Malignant hyperthermia associated with hypocalcaemia. Anesthesiology 34: 188 (1971).

174. Relton, J.E.S., Britt, B.A., \& Steward, D.J. Malignant hyperpyrexia. Brit. J. Anaesth. (In press, 1973).

175. SMTt, R.M. Temperature monitoring and regulation. Paed. Clin. of N.A. 16: 643 (1969).

176. Strobel, G.E. Treatment of anaesthetic-induced malignant hyperpyrexia. Lancet $i: 40$ (1971).

177. Snodgrass, P.J. \& Piras, M.M. The effects of halothane on rat liver mitochondria. Biochemistry 5: 1140 (1966).

178. SUMmers, R.J. Effects of monoamine oxidase inhibitors on the hypothermia produced in cats by halothane. Brit. J. Pharmac. 37: 400 (1969).

179. SUMmERs, R.J. Interaction between monoamine oxidase inhibitors and anaesthetics. In: International Symposium on Malignant Hyperthermia (ed. Gordon, Britt and Kalow), Charles C. Thomas, Springfield, p. 363 (1973).

180. Viguera, M.G. \& ConN, A.W. An investigation of general anaesthesia and hyperpyrexia in chickens. Canad. Anaesth. Soc. J. 14: 193 (1967).

181. Wang, J.K., Emerson, A.M., Moffitt, E.A., \& Rosevear, J.W. Oxidative phosphorylation in acute hyperthermia. Anesthesiology 30: 439 (1969).

182. Wilson, R.D., Nichols, R.J., Dent, T.E., \& Alien, C.R. Disturbances of the oxidativephosphorylation mechanism as a possible aetiological factor in sudden unexplained hyperthermia. Anesthesiology 26: 232 (1966).

18.3. Pennington, R.J.T. \& Worsfold, M. Biochemical studies in malignant hyperpyrexia. Proc. Roy. Soc. Med. 66: 69 (1973).

184. Beldavs, J., Small, V., Cooper, D.A., \& Brutt, B.A. Postoperative malignant hyperthermia: a case report. Canad. Anaesth. Soc. J. 18: 202 (1971).

185. Pettis, A. Personal Communication, Gary, Indiana (1972).

186. Sessions, G. Personal Communications, Atlanta, Georgia (1971).

187. WADE, J. The late treatment of malignant hyperthermia. In: International Symposium on Malignant Hyperthermia (ed. Gordon, Britt and Kalow), Charles C. Thomas, Springfield, p. 441 (1973).

188. Thompson, D.E.A. \& Tallack, J.A. Coexistent muscle disease and malignant hyperpyrexia. In: International Symposium on Malignant Hyperthermia (ed. Gordon, Britt and Kalow), Charles C. Thomas, Springfield, p. 309 ( 1973 ).

189. McComas, A. Personal Communication, Hamilton, Ontario (1972).

190. Rosalki, S.B. An improved procedure for serum creatine phosphokinase determination. J. Lab. Clin. Med. 69: 696 (1967).

191. Wroblewski, F. \& LA DuE, J.S. Lactic dehydrogenase activity in blood. Proc. Soc. Exp. Biol. Med. 90:210 (1955).

192. Jones, V.M. Personal Communication, Toronto, Ontario (1972).

193. Bucher, T., Czok, R., LAmprecht, W., \& LATzko, E. In: Methoden der Enzymatischen Analyse, ed. H.V. Bergmeyer, Verlag Chemie Weinheim, p. 253 ( 1962 ).

194. Porter, C.J. \& Kallweit, E. An automated system for measurement of calcium, magnesium and lithium in serum and urine by atomic absorption spectrophotometry. Clin. Chem. 16: 528 (1970).

195. Technicon Corporation, Ardsley, N.Y. Method N-4a (1963).

196. Frske, C.H. \& Subbarow, Y. Phosphorus compounds of muscle and liver. J. Biol. Chem. 66: $375(1925)$.

197. Buchthal, F. In: An Introduction to Electromyography. Gyldendal, Copenhagen (1957).

198. Bancroft, J.D. In: An Introduction to Histochemical Technique. Butterworth and Co., London (1967).

199. Brooke, M.H. \& ENGEL, W.K. The histographic analysis of human muscle biopsies with regard to fiber types. 1. Adult male and female. Neurology 19: 221 (1969). 
200. Macdonald, R.D., Rewcastle, N.B., \& Humphrey, J.G. The myopathy of hyperkalomic periodic paralysis - an electron microscopic study. Arch. Neurol. 19: 274 (1968).

201. Ernster, L. \& Dordenbrand, K. In: Methods in Enzymology, Vol. X, Oxidation and Phosphrylation, p. 86, Ed. R.W. Estabrook and M.E. Pullman (1967).

202. Peter, J.B. Studies of human skeletal muscle mitochondria. Biochem. Med. 2: 179 (1968).

203. Chapell, J.B. \& Perry, S.V. Biochemical and osmotic properties of skeletal muscle mitochondria. Nature, Lond. 173: 1094 ( 1954 ).

204. Layne, E. In: Methods in Enzymology, Vol. III, p. 447, eds. Colowick, S.P. and Kaplan, N.O., Academic Press (1957).

205. Dow, D.S. The isolation of skeletal muscle mitochondria showing tight coupling, high respiratory indices and differential adenosine triphosphatase activities. Biochemistry 6: 2915 (1967).

206. DundeE, J.W. Clinical pharmacology of general anesthetics. Clin. Pharmacol. and Therap. 8: 91 (1967)

207. Eger, E.I. \& Larson, C.P. Anaesthetic solubility in blood and tissues: values and significance. Brit. J. Anaesth. 36: 140 ( 1964 ).

208. Larson, C.P., Eger, E.I., \& Severinghaus, J.W. The solubility of halothane in blood and tissue homogenates. Anesthesiology 23: 349 (1962).

209. Briggs, F.N., \& Fucrs, F. The nature of the muscle-relaxing factor. I. An improved assay system. J. Gen. Physiol. 46: 883 (1963).

210. Britt, B.A., Kalow, W., \& Endrenyi, L. Effects of halothane and methoxyflurane on rat skeletal muscle mitochondria. Biochem. Pharmacol. 21: 1159 (1972).

211. Britr, B.A. Prevention of malignant hyperthermia. In: International Symposium on Malignant Hyperthermia (ed. Gordon, Britt and Kalow), Charles C. Thomas, Springfield, p. 451 (1973).

212. Brrrt, B.A. Zur behandlung der malignen hyperthermie. Der Anaesthesist $21: 201$ (1972).

213. BRITt, B.A. Malignant hyperthermia - a statistical review, II (in preparation).

214. Duma, R.J. \& Sifgel, A.L. Serum creatine phosphokinase in acute myocardial infarction. Arch. Int. Med. 115: 443 (1965).

215. Ebashi, S., Toyokura, Y., Momai, H., \& Sugita, H. High creatine phosphokinase activity of sera of progressive muscular dystrophy. Biochem. J. 46:103. (1959).

216. FUJIE, Y. Distribution of creatine phosphokinase among mammalian tissues. Seitai no Kagaku 11: 207 (1960).

217. Hess, J.W. \& MacDonald, R.P. Serum creatine phosphokinase activity - a new diagnostic aid in myocardial and skeletal muscle disease. J. Michigan State Medical Soc. 62: 1095 (1963).

218. Hess, J.W., MacDonald, R.P., \& Frederick, R.J. Serum creatine phosphokinase (CPK) activity in disorders of heart and skeletal muscle. Ann. Int. Med. 61: 1015 (1964).

219. Oktnaka, S., Kumagat, H., Ebashi, S., Sugita, H., Momoi, H., Toyokura, Y., \& FUGre, Y. Serum creatine phosphokinase - activity in progressive muscular dystrophy and neuromuscular diseases. Arch. Neurol. 4: 520 (1961).

220. Rose, L.I., Bousser, J.E., \& COOPER, K.H. Serum enzymes after marathon running. J. Appl. Physiol. 29: 355 (1970).

221. Drummond, G.I., Valdares, J.R.E., \& Duncan, L. Cardiac phosphorylase and phosphorylase kinase. In: Muscle (Paul, W.M., Daniel, E.E., Kay, C.M., and Monckton, G., eds.), Pergamon Press, Oxford (1965).

222. Ozawa, E. \& Ebashi, S. Requirement of Ca ion for the stimulating effect of cyclic 3'5'-AMP on muscle phosphorylase kinase. J. Biochem. 62: 285 (1967).

223. Ozawa, E., Hosor, K., \& EBashi, S. Reversible stimulation of muscle phosphorylase b kinase by low concentration of calcium ions. J. Biochem. 61: 531 (1967).

224. Walton, J.N., Canal, N., \& Scarlato, G. (eds.) The ultrastructure and pathogenesis of target cells. In: Muscle Diseases. Excerpta Medica, Amsterdam (1970).

225. McComas, A.J., Stca, R.E.P., \& CurRie, S. An electrophysiological study of Duchenne dystrophy. J. Neurol. Neurosurg. Psychiat. 34: 461 (1971).

226. SiCA, R.E.P. \& McComas, A.J. An electrophysiological investigation of limb-girdle and facioscapulo-humeral dystrophy. J. Neurol. Neurosurg. Psychiat. 34: 469 (1971).

227. MilLER, R.N. \& HUNTER, F.E. The effect of halothane on electron transport, oxidative phosphorylation and swelling in rat liver mitochondria. Mol. Pharmacol. 6: 67 (1970).

228. Comen, P.J., Marshall, B.E., Harris, J.E., \& Rosner, B.S. Halothane-induced changes in mitochondrial oxygen uptake and respiratory control. Fed. Proc. 27: 705 (1968). 
229. Cohen, P.J. \& Marshall, B.E. In: Toxicity of Anaesthetics (ed. B.R. Pink), Williams \& Wilkins, Baltimore, pp. 24-36 (1968).

230. Harris, R.A., Munroe, J., Farmer, B., Kim, K.C., \& Jenkins, P. Action of halothane upon mitochondrial respiration. Arch. Biochem. Biophys. 142: 435 (1971).

231. SANDOW, A. Excitation-contraction coupling in skeletal muscle. Pharmac, Rev. 17: 265 (1965).

232. Sandow, A. Skeletal muscle. Ann. Rev. Physiol. 32: 87 (1970).

233. Weber, A. \& Herz, R. The relationship between caffeine contracture of intact muscle and the effect of caffeine on reticulum. J. Gen. Physiol. 52:750 (1968).

234. Weber, A. The mechanism of the action of caffeine on sarcoplasmic reticulum. J. Gen. Physiol. 52: 760 ( 1968 ).

235. Britr, B.A. Studies in Poland China pigs affected with malignant hyperthermia (in preparation ).

236. McCarl, R.L., Margossian, S.S., Jackman, L.M., \& WEBt, R.L. Characterization of rat heart myosin. II. Enzymatic properties. Biochemistry 8: 3659 (1969).

237. Perry, S.V. Muscle proteins in contraction. In: Muscle (ed. W.M. Paul), Oxford, Pergamon Press, p. 29 ( 1965 ).

238. Perry, S.V. The role of myosin in muscular contraction. Society for Experimental Biology, Aspects of Cell Motility. 22: 1 (1968).

239. WEBER, A. \& Winicur, S. Dependence of superprecipitation of actomyosin on the concentration of ionized calcium. Fed. Proc. 20:300 (1961).

240. Weber, A. \& Herz, R. Requirement for calcium in the synaeresis of myofibrils. Biochem. Biophys. Res. Comm. 6: 364 ( 1961 ).

241. Ebashi, S. \& Enno, M. Calcium ion and muscle contraction. Progr. Biophys. Mol, Biol. 18: $123(1968)$.

242. Han, M.H. \& Benson, E.S. Conformational changes in troponin induced by $\mathrm{Ca}++$. Biochem. Biophys. Res. Comm, 28: 378 (1970).

243. Wakabayashi, T. \& Ebashi, S. Reversible change in physical state of troponin induced by calcium ion. J. Biochem. 64: 731 (1968).

244. Winegrad, S, The location of muscle calcium with respect to the myofibrils. J. Gen. Physiol. 48: 997 (1965).

245. Yasui, B., Fuchs, F., \& BRiggs, F.N. The role of the sulfhydryl groups of tropomyosin and troponin in the calcium control of actomyosin contractility. J. Biol. Chem, 243: 735 (1968).

246. Haugaard, N., Haugaard, E.S., Lee, N.H., \& Horn, R.S. Possible role of mitochondria in regulation of cardiac contractility. Fed. Proc. 28: 1657 (1969).

247. Lefininger, A.L. Mitochondria and calcium ion transport. Biochem. J. 119: 129 (1970).

248. Loyter, A., Christiansen, R.O., Steensland, H., Saltzgaber, J., \& Racken, E. Energy-linked ion translocation in sub-mitochondrial particles. I. $\mathrm{Ca}++$ accumulation in submitochondrial particles. J. Biol. Chem. 244: 4422 (1969).

249. Werer, A., Herz, R., \& Reiss, I. The regulation of myofibrillar activity by calcium. Roy. Soc. Lond. Proc. Ser. B 160: 489 (1964). 